\title{
A Multi-Omics Approach Identifies Key Regulatory Pathways Induced by Long-Term Zinc Supplementation in Human Primary Retinal Pigment Epithelium
}

\author{
Eszter Emri ${ }^{1,2}$, Elod Kortvely ${ }^{2,3}{ }^{\circledR}$, Sascha Dammeier ${ }^{3}$, Franziska Klose ${ }^{3}$, David Simpson ${ }^{1}{ }^{1}$, \\ EYE-RISK Consortium ${ }^{\dagger}$, Anneke I. den Hollander ${ }^{4}\left(\mathbb{D}\right.$, Marius Ueffing ${ }^{3}$ and Imre Lengyel ${ }^{1, *}$ (i) \\ 1 Wellcome Wolfson Institute for Experimental Medicine, Queen's University of Belfast, \\ Belfast BT97BL, Northern Ireland, UK; e.emri@qub.ac.uk (E.E.); david.simpson@qub.ac.uk (D.S.) \\ 2 Roche Pharma Research and Early Development, Immunology, Infectious Diseases and \\ Ophthalmology (I2O) Discovery and Translational Area, Roche Innovation Center Basel, F. Hoffmann-La \\ Roche Ltd., 4070 Basel, Switzerland; elod.koertvely@roche.com \\ 3 Institute for Ophthalmic Research, University of Tubingen, D-72076 Tubingen, Germany; \\ sascha.dammeier@web.de (S.D.); franziska.klose@klinikum.uni-tuebingen.de (F.K.); \\ marius.ueffing@uni-tuebingen.de (M.U.) \\ 4 Departments of Ophthalmology and Genetics, Radboud University Medical Center, \\ 6525EX Nijmegen, the Netherlands; anneke.denhollander@radboudumc.nl \\ * Correspondence: i.lengyel@qub.ac.uk; Tel.: +44-(0)-28-9097-6027 \\ + Membership of the EYE-RISK Consortium is provided in the acknowledgments.
}

Received: 17 September 2020; Accepted: 1 October 2020; Published: 6 October 2020

\begin{abstract}
In age-related macular degeneration (AMD), both systemic and local zinc levels decline. Elevation of zinc in clinical studies delayed the progression to end-stage AMD. However, the molecular pathways underpinning this beneficial effect are not yet identified. In this study, we used differentiated primary human fetal retinal pigment epithelium (RPE) cultures and long-term zinc supplementation to carry out a combined transcriptome, proteome and secretome analysis from three genetically different human donors. After combining significant differences, we identified the complex molecular networks using Database for Annotation, Visualization and Integrated Discovery (DAVID) and Ingenuity Pathway Analysis (IPA). The cell cultures from the three donors showed extensive pigmentation, development of microvilli and basal infoldings and responded to zinc supplementation with an increase in transepithelial electrical resistance (TEER) (apical supplementation: $443.2 \pm 79.3 \%$, basal supplementation: $424.9 \pm 116.8 \%$, compared to control: $317.5 \pm 98.2 \%$ ). Significant changes were observed in the expression of 1044 genes, 151 cellular proteins and 124 secreted proteins. Gene set enrichment analysis revealed changes in specific molecular pathways related to cell adhesion/polarity, extracellular matrix organization, protein processing/transport, and oxidative stress response by zinc and identified a key upstream regulator effect similar to that of TGFB1.
\end{abstract}

Keywords: zinc; retinal pigment epithelium; age-related macular degeneration; transcriptome; proteome; secretome; gene set enrichment; TGFB1

\section{Introduction}

Age-related macular degeneration (AMD) is a progressive, multi-factorial disease that leads to irreversible vision loss [1-4]. It has no cure, and only limited treatment options are available to delay, rather than prevent, the progression to end-stage AMD. Dietary intake of zinc has shown promise in delaying the progression of AMD [5-7]. 
Zinc is an essential micronutrient, critical for normal cellular processes in all organisms [8]. It acts as a catalyst for more than 300 enzymes, and thousands of proteins require zinc for their normal structure and function [9-21]. The eye has an unusually high content of zinc, primarily in the retinal pigment epithelium (RPE) [21,22]. The RPE forms a monolayer of highly specialized pigmented cells located between the neurosensory retina and the choroidal vasculature and plays a pivotal role in the visual cycle and maintaining the health of the outer retina [23]. Consequently, extensive research efforts have focused on the cell biology of the RPE [24-35] including studies examining the effects of zinc supplementation [36-38]. These studies resulted in mixed outcomes [12,39-43] likely due to the availability of zinc to exert biological function being affected by differing compositions of culture media [44]. Recently, we established the optimal conditions to study the effects of zinc on human RPE cells [38] and in this paper, we set out to identify the key regulatory pathways involved in long-term zinc supplementation by combining the zinc-induced changes in cell transcriptome and proteome and apical and basal secretomes. In this study, we identified specific regulatory pathways that might be involved in mediating the positive effects of long-term zinc supplementation in AMD.

\section{Materials and Methods}

\subsection{Retinal Pigment Epithelial (RPE) Cell Culture}

Primary human fetal RPE cells (ScienCell, Carlsbad, CA, USA) from three donors with unknown clinical or genetic background were used for our experiments at passage number three (P3). Cells were seeded onto Corning 6-well transwell inserts $(10 \mu \mathrm{m}$ thick polyester inserts with $0.4 \mu \mathrm{m}$ pore size, $4^{*} 10^{6} / \mathrm{cm}^{2}$ pore density, Corning, Wiesbaden, Germany) in epithelial cell medium (EpiCM, ScienCell, Carlsbad, CA, USA). After seven days, the cell culture medium was replaced with Miller medium with $1 \%$ FBS $[45,46]$ for an additional four weeks in the absence or presence of $125 \mu \mathrm{M}$ externally added zinc (as zinc sulphate; Thermo Fisher Scientific, Waltham, MA, USA), resulting in $~ 10 \mathrm{nM}$ bio-available or free zinc [38,44]. Cellular differentiation was monitored through the development of cobblestone morphology and increase in pigmentation using light microscopy and the increase in transepithelial electrical resistance (TEER) was measured by using the EVOM2 Epithelial Voltohmmeter and STX2 electrodes (World Precision Instruments, Sarasota, FL, USA). The obtained results were analyzed using two-way ANOVA and Tukey's test and a $p$-value $<0.05$ was considered significant.

At the end of the experiments, cells were washed with PBS (Thermo Fisher Scientific, Waltham, MA, USA) 3 times for 2 min. Then differentiation media were replaced with serum-free Minimum Essential Medium Eagle Alpha Modifications (Merck, Darmstadt, Germany). After 24 h, apical and basal media (approximately 600 and $900 \mu \mathrm{l}$, respectively) were collected, snap frozen in liquid nitrogen and stored at $-80^{\circ} \mathrm{C}$ until proteomics analysis was conducted. The transwell membranes containing the cells were excised and divided into five equal-sized wedges. These were either immediately snap frozen and kept at $-80{ }^{\circ} \mathrm{C}$ or fixed for $15 \mathrm{~min}$ in $4 \%$ PFE (Merck, Darmstadt, Germany) diluted in PBS (Thermo Fisher Scientific, Waltham, MA, USA) or kept in Karnovsky fixative (Agar, Essex, UK) comprising $3 \%(v / v)$ glutaraldehyde, $1 \%(v / v)$ paraformaldehyde in $0.08 \mathrm{M}$ sodium cacodylate buffered to $\mathrm{pH} 7.4$ with $0.1 \mathrm{M} \mathrm{HCl}$.

\subsubsection{Immunofluorescence}

For immunofluorescence analysis, the cells on the transwell membrane were permeabilized in $0.5 \%$ Triton-X (Merck, Darmstadt, Germany) in PBS for $10 \mathrm{~min}$ at $4{ }^{\circ} \mathrm{C}$ and then washed in $0.1 \%$ Tween 20 in PBS (PBST) (Merck, Darmstadt, Germany) and blocked with PBST with 5\% goat sera (Merck, Darmstadt, Germany) for one hour at room temperature. Next, samples were incubated with primary antibodies PMEL17 (Agilent, Santa Clara, CA, USA, dilution 1:25), ZO-1 (BD Biosciences, San Jose, CA, USA, 1:200), BEST-1 (Merck, Darmstadt, Germany, 1:50), and RPE65 (Merck Millipore, Darmstadt, Germany, 1:50) diluted in PBST containing 1\% goat sera. Following washing with PBST, the samples were incubated with secondary antibodies in 1:200 in PBST with 1\% goat sera for one hour 
in the dark at room temperature. After, the secondary antibody incubation samples were washed with PBST for $5 \mathrm{~min}$, followed by $5 \mathrm{~min}$ washing with PBS. Cell nuclei were then labelled for $15 \mathrm{~min}$ with DAPI (Thermo Fisher Scientific, Waltham, MA, USA) diluted 1:1,000 in PBS. Finally, the samples were washed for $5 \mathrm{~min}$ in PBS, before mounting onto Menzel-Glaser slides (Thermo Fisher Scientific, Waltham, MA, USA) in Vectashield (Vector Laboratories, Burlingame, CA, USA). The flat mounts were sealed by applying nail polish around coverslips. For negative control, the primary antibody labelling was replaced by incubation with PBST only. Results were visualized using a Leica SP8 confocal microscope (Leica, Wetzlar, Germany) with a 40x/1.25 oil immersion objective. Images were obtained and analyzed with Leica Application Suite X Image software (Leica, Wetzlar, Germany).

\subsubsection{Transmission Electron Microscopy}

For transmission electron microscopy, the 1\% glutaraldehyde (Agar, Essex, UK) and 2.5\% paraformaldehyde-fixed samples were post-fixed in 1\% (w/v) osmium tetroxide (Agar, Essex, UK) in 0.1 M PBS for $50 \mathrm{~min}$, dehydrated and embedded in Araldite (Agar, Essex, UK). Semi-thin sections were generated using Leica ultra-microtome (Leica, Wetzlar, Germany), stained with 1\% (w/v) uranyl acetate and Reynolds' lead citrate and viewed with a JEOL JEM-1010 electron microscope (JEOL USA, Peabody, MA, USA) and a Gatan Orius CCD camera (Gatan, Pleasanton, CA, USA).

\subsection{Genotyping}

For genotyping, genomic DNA was extracted from snap-frozen transwell inserts using AllPrep DNA/RNA/Protein Mini Kit (Qiagen) following manufacturers' instructions. The EYE-RISK genotyping assay [47] was used to genotype 87 single-nucleotide polymorphisms (SNPs), including the 52 independently AMD-associated SNPs identified by the International AMD Genomics Consortium [2], SNPs previously associated with AMD [48], and several candidate SNPs. For nine of the 52 AMD-associated SNPs, an alternative SNP in high linkage disequilibrium $(\geq 0.80)$ was used. Furthermore, the coding and splice-site regions of thirteen genes (C3, C9, CFH, CFI, TIMP3, SLC16A8, ARMS2, CD46, CFB, HTRA1, ABCA4, CTNNA1, and PRPH2) were completely sequenced. The targeted regions were enriched by single-molecule molecular inversion probes (smMIPs) followed by next-generation sequencing of the library pools, as described previously [47].

A genetic risk score (GRS) for the 52 AMD-associated SNPs [2] was calculated based on the formula GRS $=\sum_{i=1}^{52}\left(G_{i} \beta_{i}\right)$, as described previously [47]: $G_{1}$ represents the genotype of variant $i$, where genotypes were coded as 0,1 or 2 based on the number of minor alleles $(0=$ carrier of 0 minor alleles, $1=$ carrier of one minor allele, $2=$ carrier of two minor alleles). $\beta_{1}$ represents the effect size of variant $i$ (natural logarithm of the fully conditioned odds ratio [OR] of the minor allele of variant $i$ ), based on the genome-wide association study (GWAS) of the International Age-related Macular Degeneration Genomics Consortium (IAMDGC) [2].

\subsection{Multi-Omics Approach Development}

\subsubsection{Transcriptomics}

For transcriptomic analysis, total RNA was extracted simultaneously with genomic DNA isolation from snap-frozen transwell inserts using a AllPrep DNA/RNA/Protein Mini Kit (Qiagen) following manufacturers' instructions. The quality of RNA was analyzed using the AATI Fragment Analyzer and Qubit (Thermo Fisher). Libraries were prepared by the QUB Genomics Core technology Unit using the KAPA HyperPrep kit. Libraries were quantified, normalized and pooled in equimolar amounts and sequenced on the Illumina NextSeq 5000. QC was performed with Qualimap following alignment to human genome build GRCh37 (hg19). Raw counts calculated using htseq were analyzed further for differentially expressed genes (DEG) performing quasi-likelihood F-test in edgeR package [49]. To filter out lowly expressed genes, the following script was used: $>$ keep $<-\operatorname{rowSums}(\operatorname{cpm}(y)>0.05)>=1$. To 
be considered as DEG, the Benjamini-Hochberg-adjusted P-value was less than 0.05 . The full list and raw data are deposited in the GEO database with dataset identifier GSE156452.

\subsubsection{Proteomic Sample Preparation}

For proteomic analysis, all solvents and water were purchased from Merck (Darmstadt, Germany) as HPLC-grade purity. All chemicals were purchased from Sigma Aldrich (Taufkirchen, Germany) unless stated otherwise. HPLC columns were obtained from Thermo Fisher Scientific (Dreieich, Germany).

To analyze the secretomes of the RPE transwell cell culture, apical and basal supernatants were thawed on ice and concentrated to approximately $100 \mu \mathrm{L}$ volume by evaporation. To generate sample fractions for optional metabolomic and lipidomic analyses, in addition to proteomics the SIMPLEX extraction method was applied according to the protocol described elsewhere [50]. Finally, the methanol-containing phase was removed, and the protein pellet was air dried and frozen at $-80^{\circ} \mathrm{C}$ until further analysis.

For cellular proteomic analysis, $200 \mu \mathrm{L}$ of cold lysis buffer (Tris-buffered saline containing $1 \%$ NP-40 and 2\% cOmplete ${ }^{\mathrm{TM}}$ protease inhibitor cocktail (Merck, Darmstadt, Germany/Roche, Basel, Switzerland)) were added to one snap-frozen wedge of each transwell chamber, and the cells were detached on ice using a cell pestle (Merck, Darmstadt, Germany, \# Z359947-100EA). The resulting suspension was vortexed and subsequently centrifuged at $16,000 \times \mathrm{g}$ at $4{ }^{\circ} \mathrm{C}$ for $10 \mathrm{~min}$. The clear supernatant was recovered, and the protein concentration was determined using a conventional assay (Bradford, Biorad, California, USA). For each sample, a volume containing $10 \mathrm{mg}$ of total protein was used to perform a methanol/chloroform precipitation. The resulting protein pellet was air dried and used for proteome analysis as described in the following section.

\subsubsection{Proteome Analysis by Mass Spectrometry}

Frozen protein pellets were recovered in $30 \mu \mathrm{L}$ of $50 \mathrm{mM}$ ammonium bicarbonate solution plus an additional $4 \mu \mathrm{L}$ of RapiGest SF Surfactant (Waters, Eschborn, Germany). Proteins were reduced by adding dithiothreitol followed by an incubation with iodacetamide to alkylate cysteine residues. Finally, limited proteolysis was performed by adding $1 \mu \mathrm{L}$ of $0.5 \mu \mathrm{g} / \mu \mathrm{L}$ trypsin (Merck, Darmstadt, Germany) and incubation at $37^{\circ} \mathrm{C}$ for $12 \mathrm{~h}$. The reaction was stopped by adding trifluoroacetic acid to a final concentration of $5 \%$. After centrifugation, the supernatants were processed using StageTips (Thermo Fisher Scientific, Waltham, MA, USA) according to the manufacturer's protocol. LC-MS/MS analysis was performed on a NanoRSLC3000 HPLC system (Dionex, Thermo Fisher Scientific, Waltham, MA, USA) coupled to an Orbitrap Fusion mass spectrometer (Thermo Fisher Scientific, Waltham, MA, USA) by a nano spray ion source. Tryptic peptide mixtures were trapped on a nano trap column $(75 \mu \mathrm{m}$ i.d. $\times 2$ cm, packed with Acclaim PepMap100 C18, $3 \mu \mathrm{m}, 100 \AA$ A; Dionex, Thermo Fisher Scientific, Waltham, MA, USA), and separated on an analytical column $(75 \mu \mathrm{m}$ i.d. $\times 25 \mathrm{~cm}$, Acclaim PepMap

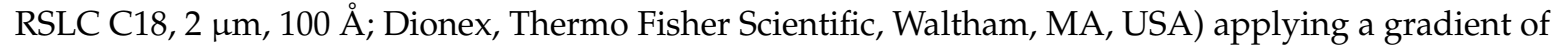
actetonitrile in water with $0.1 \%$ formic acid.

For quantitative analysis, MS raw data were processed using the MaxQuant software (version 1.5.3.30) [51]. Two missed cleavages per peptide were allowed. The peptide and protein false discovery rates were set to $1 \%$. The initial mass tolerance for precursor ions was set to $4.5 \mathrm{ppm}$ and the first search option was enabled with $20 \mathrm{ppm}$ precursor mass tolerance. The fragment ion mass tolerance was set to 0.5 Da. The SwissProt_2014 database (selected for homo sapiens, 20203 entries) was used for peptide and protein identification. The MaxQuant software-generated output file "proteingroups.txt" was utilized for Pearson correlation, clustering and statistical analysis using Perseus software version 1.5.5.3. All data were filtered for potential contaminants, peptides only identified by side or reverse sequence. The dataset was filtered further on Log2 transformed LFQ values to the minimum number of valid values "in at least one in total", and missing values were imputed using normal distribution in "separately for each column" mode. All numeric values were expressed 
as the mean \pm standard deviation (SD) for the respective groups. Benjamini-Hochberg corrections of significance B calculated by the Perseus software package were used to identify the intensity-dependent significant outliers relative to a certain populations [51]. The adjusted $p$-value of less than 0.05 was considered a significantly enriched protein. The mass spectrometry proteomics data have been deposited to the ProteomeXchange Consortium via the PRIDE [52] partner repository with the dataset identifier PXD020860.

\subsubsection{Functional Classification Pathway and Network Analysis}

Gene ontology (GO) analysis, canonical pathway and network identification were performed using Database for Annotation, Visualization and Integrated Discovery (DAVID) Bioinformatics Resources 6.8 with the Kyoto Encyclopedia of Genes and Genomes (KEGG) database [53,54], with $p$-values of less than 0.05 considered as significant enrichment. In addition, we used the Ingenuity Pathway Analysis (IPA 7.4, April 2009) with the HumanCyc database, with the default threshold of IPA, a cut-off $p$-value of -log ( $p$-value) $<1.3$ used for statistically significant enrichment for top canonical pathways. For overlapping canonical pathway visualization, the network was filtered for 250 significant pathways ( $p$-value $<0.05$ ) with a minimum of three common shared molecules. A total of 67 entries exported from relevant GWAS studies $[2,55,56]$ were used in IPA for overlaying the dataset on AMD-relevant molecules.

\section{Results}

\subsection{Characterization of Human Primary RPE Cell Culture}

Based on previous experiments [34,38], we used conditions under which RPE cells in culture developed dense microvilli (Supplementary Figure S1A), basal infoldings (Supplementary Figure S1A-C), extensive pigmentation that is localized to the apical aspects of the cells (Supplementary Figure S1A,B) with pigment particles appearing in the microvilli (Supplementary Figure S1C), basal lamina (Supplementary Figure S1D-E; red arrowheads) and expressed RPE-specific proteins such as PMEL17, ZO-1, BEST-1 and RPE65 (Supplementary Figure S1G-J, respectively). In addition, sub-RPE deposits are visible (Supplementary Figure S1D-F) similar to those of mature RPE in vivo [57,58].

While the cells from the three individuals all showed similar phenotypes (see Supplementary Figure S1), there were differences between the cultured cells. Specifically, there were differences in their pigmentation pattern (Figure 1A (donor (D)1-3)), the numbers of visible sub-RPE deposits (Figure 1A (D1-3, labelled by red arrowheads) and the maximal TEER values reached after 5 weeks in culture (Figure 1B (D1: $477.9 \pm 28.4, \mathrm{D} 2: 244.4 \pm 45$ and D3: $\left.1114.6 \pm 27 \mathrm{Ohm} \times \mathrm{cm}^{2}\right)$ ).

The genotypes of the 52 AMD-associated SNPs and rare variants in 13 genes identified in the three donors are provided in Supplementary Table S1 (genotypes different between donors are highlighted in bold). The donors had a relatively low genetic risk score (GRS) based on the 52 AMD-associated SNPs: donor 1 has a GRS of -0.33 ; donor 2 has a GRS of -2.36; and donor 3 has a GRS of 0.95 compared to the GRS of AMD patients [47]. The donors carried different genotypes for the major CFH SNP rs10922109 (donor 1 CA, donor 2 AA, donor 3 CC), and carried the same low-risk genotype for the major ARMS2 SNP rs10490924 (all three donors GG). In addition, donor 3 carries a rare, heterozygous variant in the CFI gene (c.299C > T; p.Phe100Ser) of unknown clinical significance (Supplementary Table S1, genotypes different between donors are highlighted in bold).

\subsection{Zinc and RPE Barrier Function}

Despite their differences, the cell cultures responded to zinc supplementation similarly with respect to changes in transepithelial electrical resistance (TEER) values (Figure 1C), irrespective of whether zinc was added apically or basally. Due to the differences in the maximum TEER values (Figure 1B), the zinc-induced changes in barrier function were normalized to TEER values measured at day 4 (Figure 1C). After this normalization, we found that either apical or basal zinc led to a significant 
increase in the TEER values from day 16 and this increase remained significant for the remainder of the experiment (at week 4; control: increase of $317.5 \pm 98.2 \%$, zinc basal: increase of $424.9 \pm 116.8 \%$, zinc apical: increase of $443.2 \pm 79.3 \%$ relative to day 4$)$.

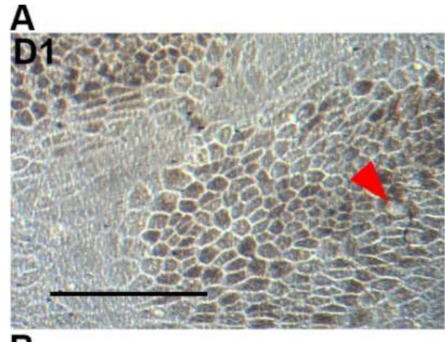

B

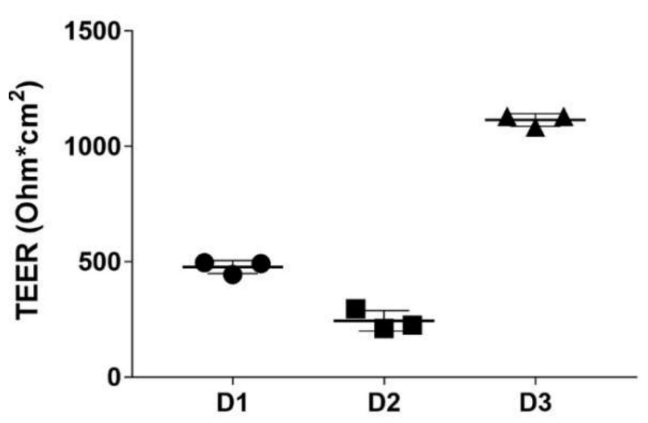

D

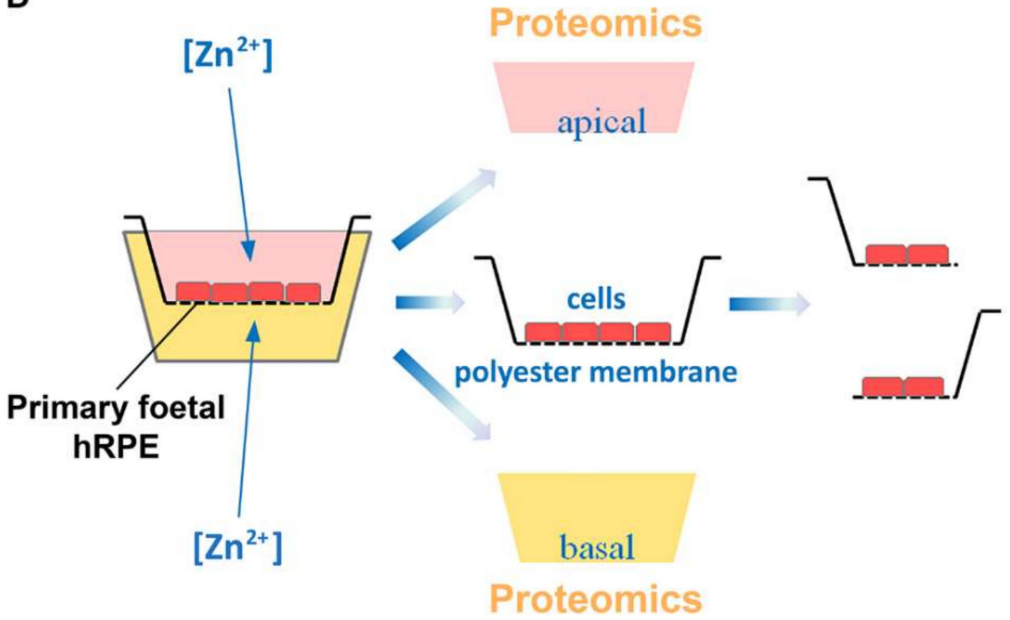

C
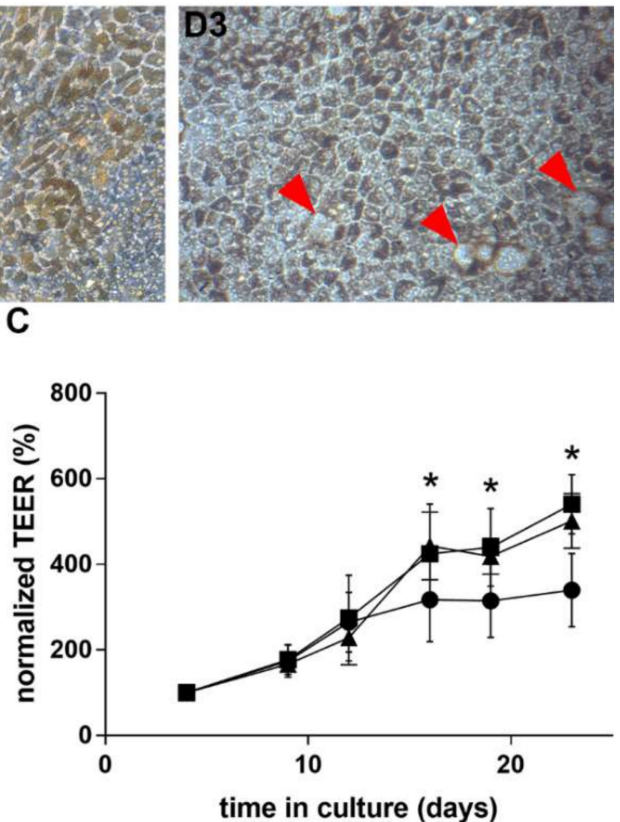

Genomics

Transcriptomics

Figure 1. Differences in characteristics between cultures from three donors. There were differences between the three batches of cells in their pigmentation (A) and maximal transepithelial electrical resistance (TEER) (B); each point is an average +/-SEM from triplicate measurements from each of three donors.). Apical and basal zinc supplementation for 4 weeks significantly increased TEER values (C); the samples from the three donors represent replicates, plotted as values normalised to $100 \%$ at day 4; control $(\bullet)$, zinc apical supplementation $(\mathbf{\bullet})$, and zinc basal supplementation $(\boldsymbol{\Lambda})$. Scale bar represents $100 \mu \mathrm{m}$. Experimental workflow for downstream analysis (D). * represents $p$-value $<0.05$, two-way ANOVA.

\subsection{Multi-Omics Approach for the Effects of Zinc on RPE}

After establishing that the cell cultures from the three donors share many phenotypic features characteristic of differentiated RPE and responded similarly to zinc treatment in terms of TEER measurement, we harvested samples for our multi-omics analysis as depicted in Figure 1D at the end of week 5 in culture. 


\subsubsection{Cellular Transcriptome}

To perform transcriptomic analysis, RNA was isolated at the end of the week 5 culturing period from the triplicate experiments. Using RNAseq, we were able to identify over 32,000 transcripts. A total of 826 of these were significantly changed in the three independent samples after apical and 216 after basal zinc supplementation when compared to untreated controls (Figure 2A, B, adjusted $p$-value $<0.05$ ). Apical zinc supplementation upregulated 415 and downregulated 411 transcripts (Figure 2A red and blue dots, respectively). Basal zinc supplementation upregulated 157 and downregulated 59 transcripts (Figure 2B). A total of 163 transcripts changed similarly after both apical and basal treatment (for the full list of significantly changed transcripts see Supplementary Table S2).
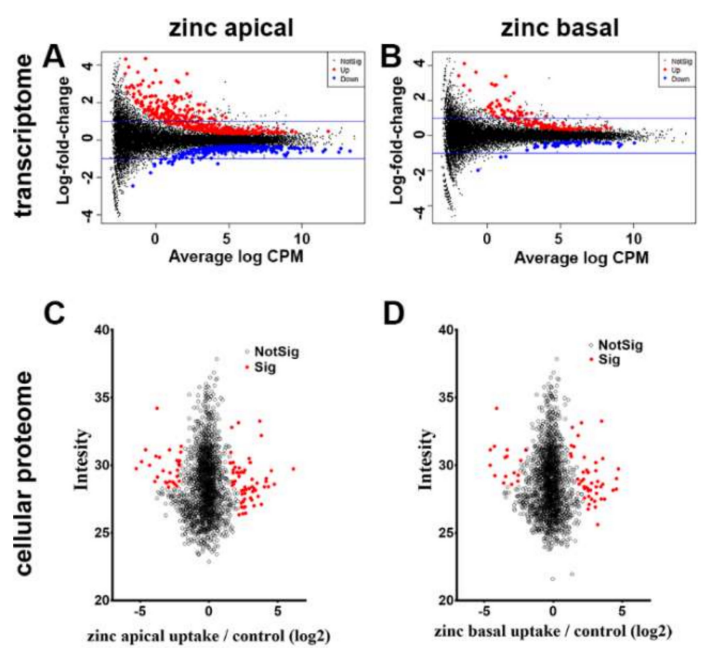

D
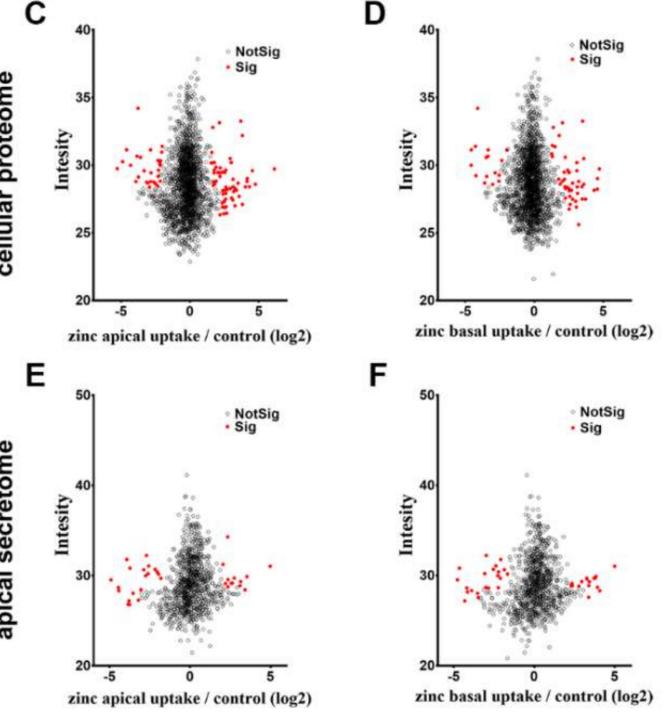

$\mathbf{F}$
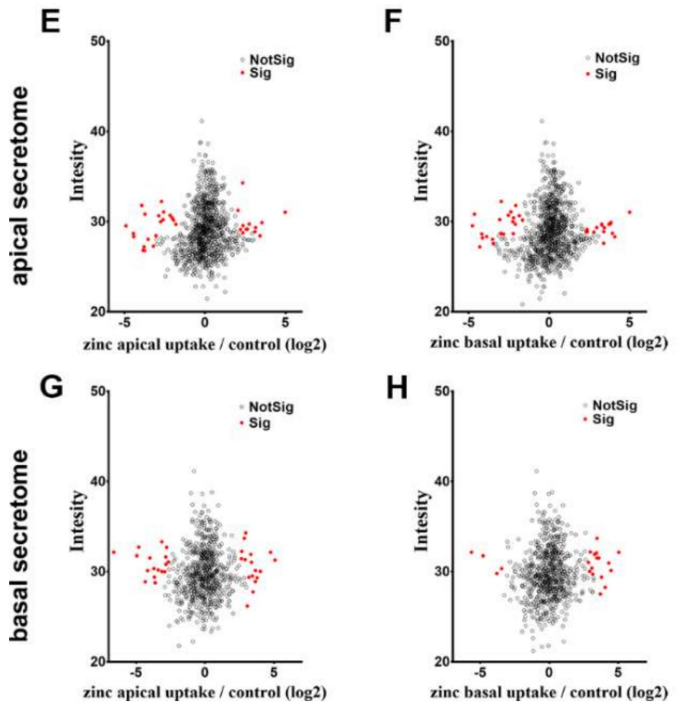

Figure 2. Changes in transcriptome and proteome following zinc supplementation. Comparison of cellular gene expressional after apical (A), or basal (B) zinc supplementation compared to untreated controls. Red dots represent significantly upregulated while blue dot represents significantly downregulated genes (adjusted $p$-value $<0.05$ ). Blue line indicates log2 fold change: 1 and -1 . Analysis of the cellular proteome following apical (C) or basal (D) zinc supplementation. When changes in secreted proteins were analysed we found significant changes in both the apical $(\mathbf{E}, \mathbf{F})$ and basal $(\mathbf{G}, \mathbf{H})$ secretomes following apical $(\mathbf{E}, \mathbf{G})$ or basal $(\mathbf{F}, \mathbf{H})$ supplementation with zinc. In $\mathrm{C}-\mathrm{H}$, open black circles represent no change while red dots show significant significance B changes (adjusted $p$-value $<0.05$ ). 


\subsubsection{Cellular Proteome}

In parallel to RNA isolation, we also isolated the protein fraction from the cells. We were able to identify 2164 proteins in the RPE cells. Following apical zinc supplementation, significant changes were observed in 89 (adjusted $p$-value $<0.05$, Figure 2C, Supplementary Table S3). Basal application of zinc resulted in significant changes in 62 proteins (adjusted $p$-value $<0.05$, Figure 2D, red dots, Supplementary Table S3). A total of 45 proteins changed similarly after both treatments.

There was an overlap in the mRNAs and proteins altered following apical supplementation of zinc (CSRP1: 1.29 and 2.52, CRIP2: 0.76 and 1.78, TTR: -0.65 and $2.6 \log _{2}$ fold change at the transcriptomic and proteomic levels, respectively, Supplementary Tables S2 and S3). After basal zinc supplementation, only CSRP1 was significantly changed in both transcriptome and proteome (CSRP1: 1.1 and $2.52 \log _{2}$ fold change, at the transcriptomic and proteomic levels, respectively, Supplementary Tables S2 and S3).

\subsubsection{Apical and Basal Secretomes}

As many proteins changed following zinc supplementation could have been secreted from cells, we collected apical and basal media for the analysis of protein secretion. We identified 1132 proteins in the apical secretomes, of which 33 changed significantly to apical and 37 to basal zinc supplementation (Figure 2E,F respectively, adjusted $p$-value $<0.05$ ). In the basal secretome, we identified 839 proteins from which 34 responded to apical (Figure 2G) and 20 to basal supplementation (Figure 2H, adjusted $p$-value $<0.05)$. Twenty-one proteins changed similarly in the apical secretome and 9 in their basal secretome after the treatments. The lists of proteins are provided in Supplementary Table S4.

Examining the overlaps between the changes in cellular transcriptome and apical secretome after apical zinc supplementation, we found two overlaps: STC2 ( 0.35 and $3.53 \log _{2}$ fold change at the transcriptomic and apical secretome levels, respectively) and TPM1 (0.47 and -2.04 log2 fold change at the transcriptomic and apical secretome levels, respectively). There were two overlaps between cellular proteome and apical secretome: PSMA3 (2.04 and -3.05 $\log 2$ fold change at the proteomic and apical secretome levels, respectively) and COL12A1 (1.59 and $-2.61 \log 2$ fold change at the proteomic and apical secretome levels, respectively) (Supplementary Tables S2-S4).

Examining the overlaps between the cellular transcriptome and apical secretome after basal zinc supplementation, we found one overlap: STC2 (5.56 and $3.84 \log 2$ fold change at the transcriptomic and apical secretome levels, respectively). There were two overlaps between cellular proteome and apical secretome: RTN4 (1.51 and $-4.2 \log 2$ fold change at the proteomic and apical secretome levels, respectively) and SERPINB12 (2.58 and $2.3 \log 2$ fold change at the proteomic and apical secretome levels, respectively) (Supplementary Tables S2-S4).

Examining the overlaps between cellular transcriptome and, this time, basal secretome after apical zinc supplementation, we found two overlaps: MYL6 (0.37 and $2.65 \log 2$ fold change at the transcriptomic and basal secretome levels, respectively) and SELENBP1 ( -0.47 and $-3.7 \log 2$ fold change at the transcriptomic and basal secretome levels, respectively). There were three overlaps between the cellular proteome and the basal secretome: ARG1 (2.36 and 3.18 log2 fold change at the proteomic and basal secretome levels, respectively), DBI (-2.02 and $2.9 \log 2$ fold change at the proteomic and basal secretome levels, respectively) and SERPINB12 (3.6 and -4.34 log2 fold change at the proteomic and basal secretome levels, respectively) (Supplementary Tables S2-S4).

When zinc was supplemented basally, there were no overlaps between the significantly changed cellular transcriptome and secreted proteins. When the cellular proteome and the basal secretomes were compared, the only significant change was observed in ARG1 (3.05 and $3.8 \log 2$ fold change for, respectively, Supplementary Tables S2-S4).

\subsection{Pathway Identification}

To evaluate the complex impact of zinc supplementation on RPE cells, we combined the significant changes in transcriptome, intracellular proteome and the basal and apical secretomes following 
either basal or apical zinc supplementation and analyzed the data by DAVID and IPA. We converted the protein symbols to gene symbols for the analysis, which resulted in 983 entries for apical and 335 entries for basal zinc treatment.

\subsubsection{DAVID Gene Ontology (GO) and KEGG Pathway Analysis}

The gene lists were first input into DAVID to identify biological processes, the involvement of cellular components, molecular functions and KEGG pathways that were significantly affected by zinc supplementation (the full list of the potential biological impacts is in Supplementary Table S5). Table 1 shows the top five most significant hits following zinc supplementation ( $p$-value $<0.05)$.

\subsubsection{IPA Canonical Pathways and Regulatory Effect Networks}

Following the analysis in DAVID, we set out to identify the canonical pathways, upstream regulators, disease associations and networks underpinning the effects of zinc supplementation by entering the data in IPA that potentially increases the statistical power of our pathway analysis by using an additional background database (summary of the analysis is in Supplementary Table S6). Table 2 shows the top five hits identified by IPA following zinc supplementation ( $p$-value $<0.05$ ).

By focusing on the top canonical pathways, we were able to identify 70 pathways after apical and 48 pathways after basal zinc supplementation $(-\log (p$-value $)<1.3$, Supplementary Table S6). There were 28 common pathways after apical and basal zinc supplementation (Supplementary Table S6).

Ostensibly unrelated canonical pathways can be interconnected through shared molecules represented by gene names. Here we determined the network of overlapping canonical pathways that shared at least three genes for both apical (Figure 3A) and basal (Figure 3B) supplementation (Supplementary Table S7). In Figure 3, each canonical pathway is shown as a single "node" (the brighter red, the more significant the pathway).

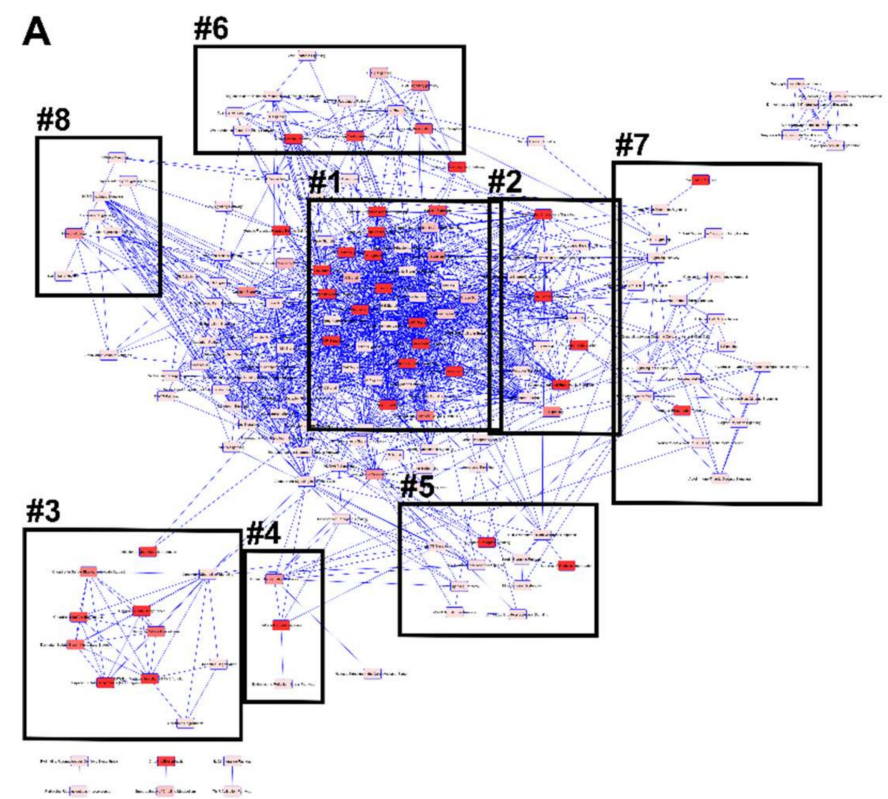

B

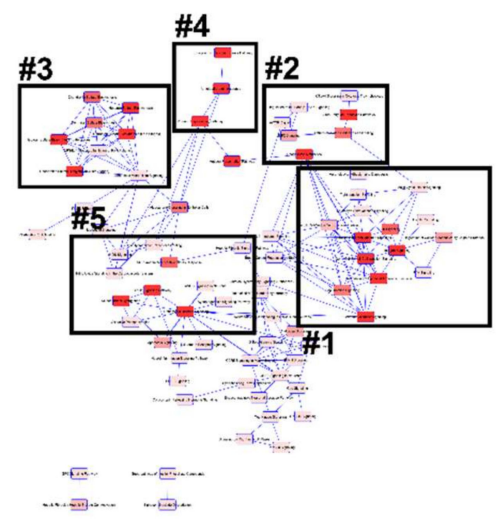

Figure 3. Overlapping canonical pathways upon zinc apical (A) or basal (B) supplementation. Each pathway is a single "node" colored according to significance (the brighter red, the more significant the pathway). Blue lines connect any two pathways which have at least three dataset molecules in common. GROUP \#1: adhesion to polarity; GROUP \#2: protein export/import; GROUP \#3: extracellular matrix organization, GROUP \#4: protein processing, GROUP \#5: oxidative stress response, GROUP \#6: embryonic cell development, GROUP \#7: immune response, and GROUP \#8: lipid metabolism. 
Table 1. The top five hits of DAVID analysis in response to zinc supplementation.

\begin{tabular}{|c|c|c|c|c|c|c|c|}
\hline \multicolumn{4}{|c|}{ Zinc Apical Supplementation } & \multicolumn{4}{|c|}{ Zinc Basal Supplementation } \\
\hline Category/Term & Count & $p$-Value & Benjamini-Hochberg & Term & Count & $p$-Value & Benjamini-Hochberg \\
\hline Biological process & & & & Biological process & & & \\
\hline $\begin{array}{l}\text { GO:0030049 muscle } \\
\text { filament sliding }\end{array}$ & 12 & 0 & 0.003 & $\begin{array}{l}\text { GO:0030198 extracellular } \\
\text { matrix organization }\end{array}$ & 14 & 0 & 0.0735 \\
\hline $\begin{array}{c}\text { GO:0051603 proteolysis } \\
\text { involved in cellular protein } \\
\text { catabolic process }\end{array}$ & 13 & 0 & 0.0027 & $\begin{array}{c}\text { GO:0030334 regulation of } \\
\text { cell migration }\end{array}$ & 9 & 0 & 0.0386 \\
\hline $\begin{array}{l}\text { GO:0001501 skeletal } \\
\text { system development }\end{array}$ & 21 & 0 & 0.0075 & $\begin{array}{c}\text { GO:0033627 cell adhesion } \\
\text { mediated by integrin }\end{array}$ & 5 & 0.0001 & 0.0617 \\
\hline $\begin{array}{l}\text { GO:0030198 extracellular } \\
\text { matrix organization }\end{array}$ & 25 & 0 & 0.0153 & $\begin{array}{l}\text { GO:2000427 positive } \\
\text { regulation of apoptotic } \\
\text { cell clearance }\end{array}$ & 4 & 0.0002 & 0.0752 \\
\hline $\begin{array}{l}\text { GO:0090090 negative } \\
\text { regulation of canonical Wnt } \\
\text { signaling pathway } \\
\text { Cellular component }\end{array}$ & 22 & 0 & 0.0187 & $\begin{array}{l}\text { GO:0051603 proteolysis } \\
\text { involved in cellular } \\
\text { protein catabolic process } \\
\text { Cellular component }\end{array}$ & 7 & 0.0002 & 0.0621 \\
\hline $\begin{array}{c}\text { GO:0070062 extracellular } \\
\text { exosome }\end{array}$ & 232 & 0 & 0 & $\begin{array}{c}\text { GO:0070062 extracellular } \\
\text { exosome }\end{array}$ & 120 & 0 & 0 \\
\hline $\begin{array}{c}\text { GO:0031012 extracellular } \\
\text { matrix }\end{array}$ & 48 & 0 & 0 & $\begin{array}{c}\text { GO:0031012 extracellular } \\
\text { matrix }\end{array}$ & 29 & 0 & 0 \\
\hline $\begin{array}{l}\text { GO:0005615 extracellular } \\
\text { space }\end{array}$ & 119 & 0 & 0 & $\begin{array}{c}\text { GO:0005615 extracellular } \\
\text { space }\end{array}$ & 60 & 0 & 0 \\
\hline GO:0005925 focal adhesion & 49 & 0 & 0 & $\begin{array}{c}\text { GO:0005925 focal } \\
\text { adhesion }\end{array}$ & 28 & 0 & 0 \\
\hline $\begin{array}{c}\text { GO:0005578 proteinaceous } \\
\text { extracellular matrix } \\
\text { Molecular function }\end{array}$ & 38 & 0 & 0 & $\begin{array}{l}\text { GO:0043209 myelin } \\
\text { sheath } \\
\text { Molecular function }\end{array}$ & 17 & 0 & 0 \\
\hline GO:0003779 actin binding & 33 & 0 & 0.0021 & $\begin{array}{c}\text { GO:0005178 integrin } \\
\text { binding }\end{array}$ & 11 & 0 & 0.0075 \\
\hline $\begin{array}{c}\text { GO:0005509 calcium ion } \\
\text { binding }\end{array}$ & 61 & 0 & 0.0034 & $\begin{array}{c}\text { GO:0001948 glycoprotein } \\
\text { binding }\end{array}$ & 8 & 0.0001 & 0.0326 \\
\hline $\begin{array}{c}\text { GO:0001948 glycoprotein } \\
\text { binding }\end{array}$ & 14 & 0 & 0.0024 & $\begin{array}{l}\text { GO:0098641 cadherin } \\
\text { binding involved in } \\
\text { cell-cell adhesion }\end{array}$ & 16 & 0.0002 & 0.0306 \\
\hline
\end{tabular}


Table 1. Cont.

\begin{tabular}{|c|c|c|c|c|c|c|c|}
\hline \multicolumn{4}{|c|}{ Zinc Apical Supplementation } & \multicolumn{4}{|c|}{ Zinc Basal Supplementation } \\
\hline Category/Term & Count & $p$-Value & Benjamini-Hochberg & Term & Count & $p$-Value & Benjamini-Hochberg \\
\hline $\begin{array}{l}\text { GO:0005200 structural } \\
\text { constituent of cytoskeleton }\end{array}$ & 16 & 0.0002 & 0.04 & $\begin{array}{l}\text { GO:0004298 threonine-type } \\
\text { endopeptidase activity }\end{array}$ & 5 & 0.0004 & 0.051 \\
\hline $\begin{array}{c}\text { GO:0008083 growth factor } \\
\text { activity }\end{array}$ & 20 & 0.0002 & 0.036 & $\begin{array}{l}\text { GO:0051015 actin } \\
\text { filament binding }\end{array}$ & 10 & 0.0005 & 0.0499 \\
\hline INTERPRO domain & & & & INTERPRO domain & & & \\
\hline $\begin{array}{l}\text { IPR013098:Immunoglobulin } \\
\text { I-set }\end{array}$ & 25 & 0 & 0 & $\begin{array}{l}\text { IPR001781:Zinc finger, } \\
\text { LIM type }\end{array}$ & 8 & 0.0002 & 0.1089 \\
\hline $\begin{array}{l}\text { IPR009030:Insulin-like } \\
\text { growth factor binding } \\
\text { protein, N-terminal }\end{array}$ & 20 & 0 & 0.0125 & $\begin{array}{l}\text { IPR001353:Proteasome, } \\
\text { subunit alpha/beta }\end{array}$ & 5 & 0.0002 & 0.0731 \\
\hline $\begin{array}{l}\text { IPR000867:Insulin-like } \\
\text { growth factor-binding } \\
\text { protein, IGFBP }\end{array}$ & 8 & 0 & 0.0086 & $\begin{array}{l}\text { IPR003096:Smooth muscle } \\
\text { protein/calponin }\end{array}$ & 4 & 0.0006 & 0.1373 \\
\hline $\begin{array}{l}\text { IPR024079:Metallopeptidase, } \\
\text { catalytic domain }\end{array}$ & 14 & 0.0001 & 0.0246 & $\begin{array}{l}\text { IPR016050:Proteasome, } \\
\text { beta-type subunit, } \\
\text { conserved site }\end{array}$ & 4 & 0.0008 & 0.1358 \\
\hline $\begin{array}{l}\text { IPR001353:Proteasome, } \\
\text { subunit alpha/beta }\end{array}$ & 7 & 0.0001 & 0.0401 & $\begin{array}{l}\text { IPR024079:Metallopeptidase, } \\
\text { catalytic domain }\end{array}$ & 7 & 0.002 & 0.2475 \\
\hline KEGG_PATHWAY & & & & KEGG_PATHWAY & & & \\
\hline $\begin{array}{l}\text { hsa04978:Mineral } \\
\text { absorption }\end{array}$ & 12 & 0 & 0.0038 & $\begin{array}{l}\text { hsa04141:Protein } \\
\text { processing in endoplasmic } \\
\text { reticulum }\end{array}$ & 12 & 0.0008 & 0.1423 \\
\hline hsa04145:Phagosome & 20 & 0.0004 & 0.0526 & hsa04145:Phagosome & 11 & 0.0012 & 0.1044 \\
\hline $\begin{array}{l}\text { hsa04350:TGF-beta } \\
\text { signaling pathway }\end{array}$ & 12 & 0.0053 & 0.3585 & $\begin{array}{l}\text { hsa04978:Mineral } \\
\text { absorption }\end{array}$ & 6 & 0.0022 & 0.1251 \\
\hline hsa03050:Proteasome & 8 & 0.0086 & 0.4214 & $\begin{array}{l}\text { hsa05410:Hypertrophic } \\
\text { cardiomyopathy (HCM) }\end{array}$ & 7 & 0.0058 & 0.2364 \\
\hline $\begin{array}{l}\text { hsa04670:Leukocyte } \\
\text { transendothelial migration }\end{array}$ & 14 & 0.0089 & 0.3623 & $\begin{array}{l}\text { hsa05414:Dilated } \\
\text { cardiomyopathy }\end{array}$ & 7 & 0.0083 & 0.2655 \\
\hline
\end{tabular}


Table 2. The top five hits of IPA analysis in response to zinc supplementation.

\begin{tabular}{|c|c|c|c|c|c|}
\hline \multicolumn{3}{|c|}{ Zinc Apical Supplementation } & \multicolumn{3}{|c|}{ Zinc Basal Supplementation } \\
\hline Canonical Pathways & $p$-value & Overlap & Canonical Pathways & $p$-value & Overlap \\
\hline ILK Signaling & $6.00 \times 10^{7}$ & $13.5 \% 25 / 185$ & Huntington's Disease Signaling & $4.48 \times 10^{6}$ & $6.4 \% 15 / 234$ \\
\hline Axonal Guidance Signaling & $1.80 \times 10^{6}$ & $9.4 \% 44 / 467$ & Unfolded Protein Response & $2.27 \times 10^{5}$ & $12.7 \% 7 / 55$ \\
\hline $\begin{array}{l}\text { Hepatic Fibrosis/Hepatic } \\
\text { Stellate Cell Activation }\end{array}$ & $5.33 \times 10^{6}$ & $12.6 \% 23 / 182$ & $\begin{array}{c}\text { Epithelial Adherens Junction } \\
\text { Signaling }\end{array}$ & $1.28 \times 10^{4}$ & $6.7 \% 10 / 150$ \\
\hline $\begin{array}{l}\text { Epithelial Adherens Junction } \\
\text { Signaling }\end{array}$ & $5.33 \times 10^{6}$ & $13.3 \% 20 / 150$ & Antigen Presentation Pathway & $2.97 \times 10^{4}$ & $13.2 \% 5 / 38$ \\
\hline Actin Cytoskeleton Signaling & $2.38 \times 10^{5}$ & $11.3 \% 24 / 213$ & Protein Ubiquitination Pathway & $3.25 \times 10^{4}$ & $4.9 \% 13 / 268$ \\
\hline $\begin{array}{l}\text { Upstream Regulators } \\
\qquad \mathrm{IgG}\end{array}$ & $\begin{array}{c}p \text {-value } \\
1.17 \times 10^{8}\end{array}$ & Predicted activation & $\begin{array}{c}\text { Upstream Regulators } \\
\text { MRTFB }\end{array}$ & $\begin{array}{c}p \text {-value } \\
5.96 \times 10^{7}\end{array}$ & Predicted Activation \\
\hline FSH & $1.06 \times 10^{6}$ & & TP63 & $1.88 \times 10^{6}$ & \\
\hline MRTFB & $3.47 \times 10^{6}$ & Activated & FSH & $2.66 \times 10^{6}$ & \\
\hline TEAD1 & $3.65 \times 10^{6}$ & & TEAD2 & $2.39 \times 10^{5}$ & \\
\hline TEAD4 & $3.65 \times 10^{6}$ & & TEAD3 & $2.79 \times 10^{5}$ & \\
\hline Diseases and Disorders & $p$-value range & \# Molecules & Diseases and Disorders & $p$-value range & \# Molecules \\
\hline Neurological Disease & $7.89 \times 10^{4}-4.57 \times 10^{18}$ & 315 & Endocrine System Disorders & $6.67 \times 10^{4}-1.30 \times 10^{11}$ & 235 \\
\hline Cancer & $7.89 \times 10^{4}-4.69 \times 10^{15}$ & 862 & $\begin{array}{l}\text { Organismal Injury and } \\
\text { Abnormalities }\end{array}$ & $7.23 \times 10^{4}-1.30 \times 10^{11}$ & 312 \\
\hline $\begin{array}{l}\text { Organismal Injury and } \\
\text { Abnormalities }\end{array}$ & $7.89 \times 10^{4}-4.69 \times 10^{15}$ & 873 & Hereditary Disorder & $7.23 \times 10^{4}-1.58 \times 10^{10}$ & 95 \\
\hline Gastrointestinal Disease & $7.70 \times 10^{4}-9.48 \times 10^{14}$ & 774 & Neurological Disease & $6.61 \times 10^{4}-1.58 \times 10^{10}$ & 102 \\
\hline Cardiovascular Disease & $6.50 \times 10^{4}-3.14 \times 10^{13}$ & 203 & $\begin{array}{c}\text { Skeletal and Muscular } \\
\text { Disorders }\end{array}$ & $7.23 \times 10^{4}-1.58 \times 10^{10}$ & 116 \\
\hline $\begin{array}{l}\text { Molecular and Cellular } \\
\text { Functions }\end{array}$ & $p$-value range & \# Molecules & $\begin{array}{l}\text { Molecular and Cellular } \\
\text { Functions }\end{array}$ & $p$-value range & \# Molecules \\
\hline Cellular Movement & $4.19 \times 10^{4}-7.88 \times 10^{19}$ & 189 & Cellular Movement & $2.47 \times 10^{4}-1.06 \times 10^{9}$ & 64 \\
\hline Molecular Transport & $7.25 \times 10^{4}-6.55 \times 10^{9}$ & 108 & Protein Synthesis & $1.31 \times 10^{6}-6.82 \times 10^{8}$ & 40 \\
\hline $\begin{array}{l}\text { Cellular Assembly and } \\
\text { Organization }\end{array}$ & $5.34 \times 10^{4}-3.26 \times 10^{8}$ & 105 & Cellular Compromise & $7.45 \times 10^{6}-2.64 \times 10^{7}$ & 29 \\
\hline Protein Synthesis & $1.12 \times 10^{5}-4.12 \times 10^{7}$ & 81 & Molecular Transport & $5.71 \times 10^{4}-2.64 \times 10^{7}$ & 44 \\
\hline Cell Death and Survival & $6.87 \times 10^{4}-9.45 \times 10^{7}$ & 132 & Cell Death and Survival & $4.86 \times 10^{4}-3.59 \times 10^{7}$ & 58 \\
\hline $\begin{array}{l}\text { Physiological System } \\
\text { Development and Function }\end{array}$ & $p$-value range & & $\begin{array}{c}\text { Physiological System } \\
\text { Development and Function }\end{array}$ & $p$-value range & \# Molecules \\
\hline $\begin{array}{l}\text { Cardiovascular System } \\
\text { Development and Function }\end{array}$ & $6.97 \times 10^{4}-2.19 \times 10^{10}$ & 94 & $\begin{array}{l}\text { Cardiovascular System } \\
\text { Development and Function }\end{array}$ & $1.58 \times 10^{4}-1.74 \times 10^{7}$ & 42 \\
\hline
\end{tabular}


Table 2. Cont

\begin{tabular}{|c|c|c|c|c|c|}
\hline \multicolumn{3}{|c|}{ Zinc Apical Supplementation } & \multicolumn{3}{|c|}{ Zinc Basal Supplementation } \\
\hline Organismal Development & $6.97 \times 10^{4}-2.19 \times 10^{10}$ & 118 & Organismal Development & $5.68 \times 10^{4}-1.74 \times 10^{7}$ & 41 \\
\hline Tissue Development & $6.97 \times 10^{4}-4.23 \times 10^{7}$ & 132 & Organ Morphology & $1.20 \times 10^{4}-6.53 \times 10^{7}$ & 9 \\
\hline $\begin{array}{l}\text { Skeletal and Muscular System } \\
\text { Development and Function }\end{array}$ & $5.80 \times 10^{4}-4.99 \times 10^{6}$ & 31 & Tissue Development & $5.68 \times 10^{4}-2.49 \times 10^{4}$ & 26 \\
\hline Tissue Morphology & $1.93 \times 10^{5}-1.93 \times 10^{5}$ & 12 & $\begin{array}{c}\text { Connective Tissue Development } \\
\text { and Function }\end{array}$ & $5.68 \times 10^{4}-2.84 \times 10^{4}$ & 19 \\
\hline Regulator Effect Networks & $\begin{array}{l}\text { Disease and } \\
\text { Functions }\end{array}$ & Consistency Score & Regulator Effect Networks & disease and functions & Consistency Score \\
\hline TGFB1 & $\begin{array}{c}\text { Progressive } \\
\text { neurological disorder }\end{array}$ & 0 & - & & \\
\hline Networks & Score & & Networks & Score & \\
\hline $\begin{array}{c}\text { Cellular Movement, Immune } \\
\text { Cell Trafficking }\end{array}$ & 33 & & $\begin{array}{l}\text { Amino Acid Metabolism, } \\
\text { Post-Translational Modification, } \\
\text { Small Molecule Biochemistry }\end{array}$ & 41 & \\
\hline $\begin{array}{l}\text { Cell Cycle, Cellular } \\
\text { Development }\end{array}$ & 33 & & $\begin{array}{l}\text { Cellular Movement, Cell Death } \\
\text { and Survival, Cell-To-Cell } \\
\text { Signaling and Interaction } \\
\text { Cardiovascular System }\end{array}$ & 37 & \\
\hline $\begin{array}{l}\text { Cell Death and Survival, } \\
\text { Molecular Transport }\end{array}$ & 31 & & $\begin{array}{l}\text { Development and Function, } \\
\text { Organ Development, Organ } \\
\text { Morphology }\end{array}$ & 32 & \\
\hline $\begin{array}{c}\text { Cancer, Organismal Injury and } \\
\text { Abnormalities, Reproductive } \\
\text { System Disease }\end{array}$ & 31 & & $\begin{array}{l}\text { Cellular Movement, } \\
\text { Cell-To-Cell Signaling and } \\
\text { Interaction }\end{array}$ & 18 & \\
\hline $\begin{array}{l}\text { Cellular Development, Cellular } \\
\text { Growth and Proliferation }\end{array}$ & 27 & & $\begin{array}{c}\text { Endocrine System Disorders, } \\
\text { Gastrointestinal Disease, } \\
\text { Metabolic Disease }\end{array}$ & 16 & \\
\hline
\end{tabular}


Overlapping pathways identified five distinct clusters of which there were four small clusters (pyrimidine ribonucleotides de novo biosynthesis and interconversion; citrulline biosynthesis and metabolism; IL-23 and Th17 activation; phosphoinositide biosynthesis, metabolism and degradation) and one large cluster (the full list of canonical pathways are listed in Supplementary Table S7) with several highly interconnected canonical pathways after apical zinc supplementation (Figure 3A).

Following basal zinc supplementation, we identified three separate clusters with two small clusters (GP6 and hepatic fibrosis/hepatic stellate cell activation; super pathway of inositol phosphate compounds; and phosphoinositide degradation) and one large cluster (the full list of canonical pathways are listed in Supplementary Table S7) with multiple interconnected canonical pathways (Figure 3B).

Within the large clusters, we identified eight groups after apical supplementation and five groups after basal supplementation (groups are demarcated by black squares in Figure 3; Supplementary Table S7). The five groups identified after basal supplementation are all present after apical supplementation (adhesion to polarity, protein export/import, extracellular matrix organization, protein processing and oxidative stress). Three unique groups (Groups \#6, \#7 and \#8, embryonic cell development, lipid metabolism and immune response) were identified after apical supplementation.

Regulator effects explain how predicted activated or inhibited upstream regulators might cause increases or decreases in phenotypic or functional outcomes downstream (for more details, see [59]). The regulator effects enrichment analysis in IPA predicted one directionally coherent network with TGFB1 as potential upstream regulator effect, but only when cells were supplemented with apical zinc (Figure 4). VIM, MMP2, CDKN1A, SERPINA1, F3 (also known as Tissue Factor), miR-145, and FAS dataset genes were identified as TGFB1-targeted downstream master regulators. The predicted disease mechanism was the inhibition of progressive neurological disorder (Figure 4). There was no regulator effect enrichment identified after basal zinc application.

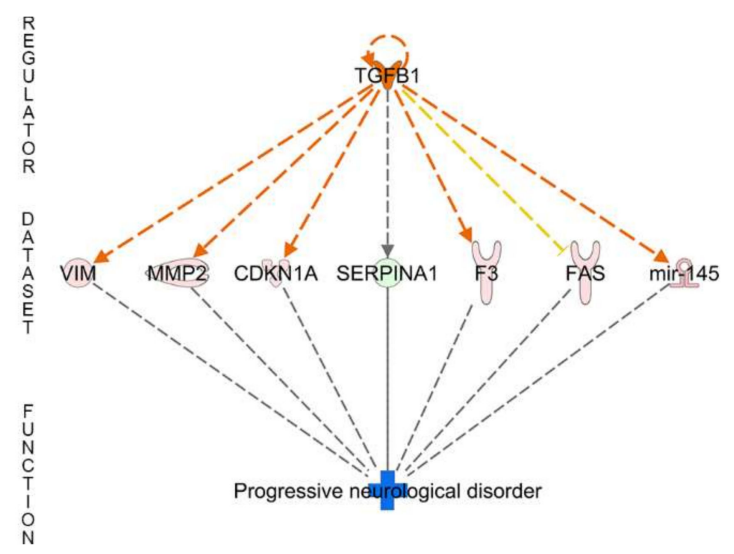

Figure 4. Influence of zinc supplementation culturing condition in retinal pigment epithelial cells. Measured and predicted upstream and downstream regulatory effect. Orange lines and objects: predicted activation; grey lines: not predicted effect; yellow lines: inconsistency with state of downstream molecule; light red objects: measured increase; green object: measured decrease; blue object: predicted inhibition. Note, this regulatory effect of TGFB1 was only detected upon zinc apical supplementation.

\section{Discussion}

Identification of molecular pathways involved in the progression to late stages of AMD is vital to develop new or improved intervention strategies to stop the development of irreversible visual loss. One of the proposed intervention strategies for AMD is to modify the intake of a group of molecules that includes zinc [60]. Based on the Rotterdam study [61], Blue Mountains Eye study [62] and AREDS study [60], restoring zinc balance can slow the progression to end-stage AMD [5-7,63]. However, 
the molecular networks involved in this beneficial effect are not fully understood. In this work, we identified potential key regulatory pathways through which zinc may exert its positive effects in vivo.

To study the effects of zinc supplementation, we used a human fetal primary RPE cell culture model for AMD. This model has been shown to recapitulate aspects of early AMD including deposition of sub-RPE material [34]. We followed protocols from these earlier studies to ensure best culturing conditions and that sufficient zinc is available for the culture without causing cell toxicity $[38,44]$.

While chronic exposure to elevated zinc reproduced the increased TEER and enhanced cell pigmentation as reported earlier [38], there were significant individual differences between maximal TEER values, levels of pigmentation and numbers of sub-RPE deposits in the primary RPE cell cultures derived from three different donors (Figure 1). These differences are likely to reflect genetic and phenotypic variations between individual donors from whom the cells were isolated from and may reflect the variability among individuals in real life. These individual differences also suggest that using precision medicine in the treatment of AMD can result in immense patient benefits.

Chronic treatment usually results in homeostatic cellular re-balancing [64] which may explain the observed moderate fold changes in our experiments. However, the long-term supplementation is aimed to reflect the long-term influence of zinc nutrition or supplementation used in population based studies $[5-7,63]$.

In our previous study, we only applied zinc apically [38]. However, in vivo zinc supplementation would likely affect both basal and apical zinc availability. In this study, the basal elevation of zinc was designed to mimic changes associated with altered zinc concentration in the sub-RPE space, probably through transport from the systemic circulation via the choroidal vessels, while the apical supplementation was designed to replicate changes in zinc concentration in the sub-retinal space, where the photoreceptors and the interphotoreceptor matrix form an interdigitated layer with the apical surface of the RPE.

To evaluate the complex effects of zinc supplementation, we combined the significant changes observed in the transcriptome, proteome and secretomes of RPE after either apical or basal supplementation and performed analysis using DAVID and IPA for pathway identification. Both analyses revealed five main biological functions shared between apical and basal zinc supplementation: oxidative stress response, protein processing, protein export/import, adhesion to polarity and extracellular matrix organization (summarized with grouping of overlapping canonical pathways in Supplementary Figure S2). Zinc is known to affect oxidative processes by modulating the expression of metallothioneins [65,66], glutathione [67-69], and catalase [12,42], by stabilizing sulfhydryl groups on proteins [70] and by replacing redox-active metals, such as copper and iron [71,72]. With ageing in general and in AMD in particular, protein, lipid and mineral-rich deposits accumulate in the sub-RPE space. The effects on protein processing and protein export/import in this study suggest that zinc supplementation might modulate directly sub-RPE accumulation. The effects of zinc in sub-RPE deposit formation in clinical studies are varied (see review [73,74]) and will require further investigations, probably with the use of methods that are able to specifically identify sub-RPE deposits in a clinical setting [75-77]. Changes in cell adhesion to polarity [78] and modulation of extracellular matrix organization had also been reported in AMD [31,79] which highlight another layer of complexity of zinc action on the RPE. As RPE activation and migration are significant clinical signs of the progression of AMD [80], this finding could point to new studies in which the clinical effects of zinc could be evaluated based on these new clinical endpoints. Overall, these findings highlight that zinc supplementation or increased nutrient intake have diverse effects on the RPE. Given that both apical and basal supplementation triggered these biological effects, increasing zinc concentration in the retina or in the blood circulation appears to be beneficial in AMD.

However, there were several biological functions affected specifically following apical zinc supplementation in our experiments. It is not yet known how the availability of zinc is regulated in health or in disease in the subretinal space. In the photoreceptor outer segments there is a high demand for zinc for the normal function of opsins [81-83]. This demand could be served by the release of zinc 
from the zinc-rich RPE [84], transport through the RPE from the choroid via zinc specific transport mechanisms [85,86] or release of zinc from the Müller glia [87]. As availability of apical zinc is critical for maintaining the high demand for the visual cycle [81-83,88-91] examining effects of increased apical zinc further.

The biological functions affected specifically by apical zinc supplementation were embryonic cell development, immune response and lipid metabolism. Differentiation and dedifferentiation of RPE had been linked with AMD [92]. Zinc is a known effector of infection and immunity via NF-kappaB activation and its targets such as TNF-alpha, IL-1beta, A20 and PPAR-alpha and inhibition of cyclic nucleotide phosphodiesterase [71,93] and as inflammation is strongly associated with AMD [57,94-96] our findings suggest that further clinical investigations are needed to uncover the relationship between zinc and the immune function. In addition, disturbances in lipid metabolism, both genetically and functionally, in AMD are well documented (for review see [97]). Therefore, these specific apical effects observed in our study suggest potential targets of zinc supplementation that could be studied further to identify new mediators for the progression of AMD in vivo.

We also investigated how the effect of zinc might directly link with the genes whose polymorphisms have been independently associated with AMD [2,55,56]. From these 67 AMD-associated genes, apical zinc supplementation influenced 6, and basal zinc supplementation affected one gene (Supplementary Figure S3). Amongst these, we found a significantly increased expression of CFI following basal zinc supplementation. Zinc supplementation in AMD patients has been shown to reduce the activity of the complement system [98] and our results on CFI suggest that this reduced activity might be due to the increased expression of CFI. Another regulator of the complement system is CFH, one of the most significantly associated gene in relationship to AMD [2,55]. In our study, we found inconsistent zinc induced changes in both CFH transcripts, intracellular or secreted protein levels which might be due to low sample size and our donor to donor variability in the CFH genotype (Supplementary Tables S1-S4). Another major AMD gene association is related to HTRA1/ARMS2, and we found a significant increase in cellular HTRA1 protein levels, although there was no significant change observed in the transcriptome or apical or basal secretomes (Supplementary Tables S2-S4). Whether the significant cellular change is related to the fact that all three donors were homozygous for the low-risk ARMS2 rs10490924 and HTRA1 rs11200638 genotype needs further examination on larger samples sizes. The direct clinical implications of zinc supplementation regarding these genes are highlighted in the recent controversy regarding the role of zinc in AMD progression in the AREDS study. Awh et al. [99] reported that patients with two CFH risk alleles and no ARMS2 alleles progressed more frequently to late AMD when supplemented with zinc, while those with no or just one $C F H$ risk allele and one or two ARMS2 risk alleles did benefit from zinc supplementation. These results, however, could not be replicated by Chew et al. [100]. Together with our data, further examination of zinc and genotype/protein activity might be highly relevant for AMD patients.

Regulator effects analysis in IPA enables generation of a hypothesis for how a phenotype, function or disease is regulated in a dataset by activated or inhibited upstream regulators. While there were no regulator effects predicted for basal zinc supplementation, apical zinc supplementation identified TGFB as a predicted master regulator (Figure 4). There is an emerging role for TGFB signaling in AMD [101,102] partly due to its role in angiogenesis [103]. Interestingly, its role in AMD is likely to be related to its receptor (TGFBR1) in RPE rather than the TGFB itself [101,102]. TGFB secreted by choroidal macrophages [102] seems to elicit secretion of VEGF by RPE leading to changes in vascular behavior [102]. While TGFB was expressed in our model, confirming a previous report [104], its levels were not modulated by changing zinc. However, downstream targets for TGFB, such as VIM (vimentin), MMP2, CDKN1A, SERPINA1, miR-145, F3 (tissue factor) and FAS, were all modulated by apical zinc supplementation (Figure 4). Vimentin directly interact with zinc and this interaction affects its assembly as well as redox sensing [105]. Due to its association with epithelial-mesenchymal transition, pigmentary abnormalities as well as the migration of RPE, vimentin also plays a role in the pathogenesis of AMD [106,107]. MMPs and their inhibitors play a role in the pathogenesis of 
AMD [108] [109,110] by reorganizing the extracellular matrix [111] and reduction in the build up of sub-RPE material [58]. CDKN1A is involved in RPE differentiation, proliferation, migration, and cell-cycle progression [112]. As such, CDKN1A plays a role in the ageing process of RPE and hence in AMD [113]. SERPINA1 is serine protease inhibitor and has a role in prevention against tissue destruction [114]. This protein was reported as a component of drusen [115] and its level in vitreous is directly associated with neovascular AMD and linked to increased immune response [116]. miR-145 is a biomarker for early detection of congenital hemochromatosis in AMD [117] and neovascular AMD [118]. miR-145 downregulates junctional cell adhesion molecules and actin-bundling proteins, resulting in a reduction in cell motility [119]. Tissue factor (F3) has been significantly upregulated in human macular lesions in AMD, initiating intracellular signaling and promoting inflammation and angiogenesis $[120,121]$. Finally, FAS-mediated apoptosis has been shown to be involved in AMD [122] via mediating RPE survival under oxidative stress conditions [123]. Therefore, it is possible that zinc might replace/substitute TGFB in eliciting a positive response in AMD.

\section{Conclusions}

In summary, we found that zinc supplementation has the potential to directly influence a number of molecular pathways. In a multi-factorial disease such as AMD, these wide-ranging effects are probably not surprising. The finding that zinc could act as a potential master regulator similar to that of TGFB1 might help to explain the benefit observed in clinical studies. Studies with a larger sample size and cells directly derived from AMD patients might help to refine our observations.

Supplementary Materials: The following are available online at http://www.mdpi.com/2072-6643/12/10/3051/s1, Figure S1: Characterization of the human primary RPE cell model; Figure S2: Regulatory cellular biological processes; Figure S3: Significant changes of AMD-associated genes upon zinc apical (a) or basal (b) supplementation; Table S1 (spreadsheet): Genotype of RPE; Table S2 (spreadsheet): Transcriptome of RPE; Table S3 (spreadsheet): Proteome of RPE; Table S4 (spreadsheet): Secretome of RPE; Table S5 (spreadsheet): DAVD analysis; Table S6 (spreadsheet): IPA analysis; Table S7 (spreadsheet): Overlapping canonical pathways; Table S8 (spreadsheet): EYE-RISK member list.

Author Contributions: Conceptualization, E.E., I.L. and E.K.; Methodology, E.E., S.D., F.K., D.S. and A.I.D.H.; Investigation, E.E., I.L. and E.K.; Formal Analysis and Visualization, E.E., E.K. and I.L.; Writing-Original Draft, E.E. and I.L.; Writing-Review and Editing, E.E., D.S., E.K. and EYE-RISK Consortium members; Supervision and Funding Acquisition, M.U., I.L. and E.K. All authors have read and agreed to the published version of the manuscript.

Funding: This work was supported by the EYE-RISK project funded by the European Union's Horizon 2020 research and innovation program under grant agreement no. 634479 and an unrestricted postdoctoral fellowship from F. Hoffmann La Roche Ltd. (E.E.).

Acknowledgments: We would like to thank Dervla McCloskey for her technical assistance for immunostaining of retinal pigment epithelial cell cultures. The authors gratefully acknowledge the QUB Genomics Core Facility for their expertise and assistance in this work. EYE-RISK consortium members as collaborators: Erkin Acar 1, Soufiane Ajana 2, Blanca Arango-Gonzalez 3, Angela Armento 3, Franz Badura 4, Ulrich Bartz-Schmidt 5, Marc Biarnes 6, Anna Borrell 6, Anita de Breuk 1, Berta De la Cerda 7, Johanna M. Colijn 8, Audrey Cougnard-Gregoire 2, Cecile Delcourt 2, Sigrid Diether 3, Eszter Emri 9,11, Tanja Endermann 10, Lucia L. Ferraro 6, Miriam Garcia 6, Thomas J. Heesterbeek 1, Anneke I. den Hollander 1, Sabina Honisch 3, Ellen Kilger 3, Caroline C. W. Klaver 1, 8, Elod Kortvely 11, Hanno Langen 11, Imre Lengyel 9, Magda Meester-Smoor 8, Benedicte M. J. Merle 2, Jordi Mones 6, Everson Nogoceke 11, Tunde Peto 9, Frances M. Pool 12, Eduardo Rodriguez 6, Jose Sousa 13, Eric Thee 8, Marius Ueffing 3, Timo Verzijden 8, Markus Zumbansen 10. 1 Departments of Ophthalmology and Genetics, Radboud University Medical Center, 6525EX Nijmegen, the Netherlands; erkin.acar@radboudumc.nl, Anita.deBreuk@radboudumc.nl, Tom.Heesterbeek@radboudumc.nl, Anneke.denHollander@radboudumc.nl. 2 Univ. Bordeaux, Inserm, Bordeaux Population Health Research Center, UMR 1219 Bordeaux, France; Soufiane.Ajana@u-bordeaux.fr, Audrey.Cougnard-Gregoire@isped.u-bordeaux2.fr, cecile.delcourt@u-bordeaux.fr, Benedicte.Merle@u-bordeaux.fr. 3 Institute for Ophthalmic Research, University of Tubingen, D-72076 Tubingen, Germany; blanca.arango-gonzalez@klinikum.uni-tuebingen.de, angela.armento@uni-tuebingen.de,_sigrid.diether@uak-swm.de, sabina.honisch@uni-tuebingen.de, ellen.kilger@uni-tuebingen.de, marius.ueffing@uni-tuebingen.de. 4 PRO RETINA Deutschland e.V. Franz.Badura@t-online.de. 5 University Eye Hospital, University of Tubingen, D-72076 Tubingen, Germany; U.Bartz-Schmidt@uni-tuebingen.de. 6 Barcelona Macula Foundation, Barcelona, Spain; Institut de la Màcula, 8022 Barcelona, Spain; mbiarnes@barcelonamaculafound.org, aborrell@barcelonamaculafound.org, lferraro@barcelonamaculafound.org,mgarcia@barcelonamaculafound.org, jmones@barcelonamaculafound.org, 
erodriguez@barcelonamaculafound.org. 7 Regeneration and Cell Therapy Department, Andalusian Molecular Biology and Regenerative Medicine Centre-CABIMER (Junta de Andalucía), CSIC, Universidad de Sevilla, 41092 Seville, Spain; berta.delacerda@cabimer.es. 8 Department of Ophthalmology and Epidemiology, Erasmus Medical Center, 3000 CA Rotterdam, the Netherlands; j.m.colijn@erasmusmc.nl, c.c.w.klaver@erasmusmc.nl, m.meester-smoor@erasmusmc.nl, e.thee@erasmusmc.nl, t.verzijden@erasmusmc.nl. 9 Wellcome Wolfson Institute for Experimental Medicine, Queen's University of Belfast, BT9 7BL Belfast, Northern Ireland, UK; e.emri@qub.ac.uk, i.lengyel@qub.ac.uk, t.peto@qub.ac.uk.10 AYOXXA Biosystems GmbH, D-50829 Cologne, Germany; tanja.endermann@ayoxxa.com, markus.zumbansen@ayoxxa.com. 11 Roche Pharma Research and Early Development, Immunology, Infectious Diseases and Ophthalmology (I2O) Discovery and Translational Area, Roche Innovation Center Basel, F. Hoffmann-La Roche Ltd., 4070 Basel, Switzerland; elod.koertvely@roche.com, hanno.langen@roche.com, everson.nogoceke@roche.com. 12 UCL Institute of Ophthalmology and NIHR Moorfields Biomedical Research Centre, University College London, EC1V 9EL London, UK; f.pool@ucl.ac.uk. 13 Faculty of Medicine, Health and Life Sciences, Queen's University of Belfast, BT9 7BL Belfast, Northern Ireland, UK; j.sousa@qub.ac.uk.

Conflicts of Interest: E Nogoceke and E. Kortvely are employees of F. Hoffmann-La Roche Ltd., Basel, Switzerland. Sacha Dammeier is an employee at Erbe Elektromedizin GmbH. Tanja Endermann and Markus Zumbansen are employees of AYOXXA Biosystems. Cécile Delcourt is a consultant for Allergan, Bausch+Lomb, Laboratoires Théa, Novartis, F. Hoffmann-La Roche Ltd. Marc Biarnés has received travel fees from Bayer and consultant for F. Hoffmann-La Roche Ltd. The other authors have no relevant affiliations or financial involvement with any organization or entity with a financial interest in or financial conflict with the subject matter or materials discussed in the manuscript.

\section{References}

1. DeAngelis, M.M.; Owen, L.A.; Morrison, M.A.; Morgan, D.J.; Li, M.; Shakoor, A.; Vitale, A.; Iyengar, S.; Stambolian, D.; Kim, I.K.; et al. Genetics of age-related macular degeneration (AMD). Hum. Mol. Genet. 2017, 26, R246. [CrossRef] [PubMed]

2. Fritsche, L.G.; Igl, W.; Bailey, J.N.; Grassmann, F.; Sengupta, S.; Bragg-Gresham, J.L.; Burdon, K.P.; Hebbring, S.J.; Wen, C.; Gorski, M.; et al. A large genome-wide association study of age-related macular degeneration highlights contributions of rare and common variants. Nat. Genet. 2016, 48, 134-143. [CrossRef] [PubMed]

3. Lim, L.S.; Mitchell, P.; Seddon, J.M.; Holz, F.G.; Wong, T.Y. Age-related macular degeneration. Lancet 2012, 379, 1728-1738. [CrossRef]

4. Bourne, R.R.; Stevens, G.A.; White, R.A.; Smith, J.L.; Flaxman, S.R.; Price, H.; Jonas, J.B.; Keeffe, J.; Leasher, J.; Naidoo, K.; et al. Causes of vision loss worldwide, 1990-2010: a systematic analysis. Lancet Glob. Health 2013, 1, e339-e349. [CrossRef]

5. Van Leeuwen, R.; Boekhoorn, S.; Vingerling, J.R.; Witteman, J.C.; Klaver, C.C.; Hofman, A.; De Jong, P.T. Dietary intake of antioxidants and risk of age-related macular degeneration. JAMA 2005, 294, 3101-3107. [CrossRef]

6. Age-Related Eye Disease Study Research Group. A randomized, placebo-controlled, clinical trial of high-dose supplementation with vitamins $\mathrm{C}$ and $\mathrm{E}$, beta carotene, and zinc for age-related macular degeneration and vision loss: AREDS report no. 8. Arch. Ophthalmol. 2001, 119, 1417-1436. [CrossRef]

7. Tan, J.S.; Wang, J.J.; Flood, V.; Rochtchina, E.; Smith, W.; Mitchell, P. Dietary antioxidants and the long-term incidence of age-related macular degeneration: the Blue Mountains Eye study. Ophthalmology 2008, 115, 334-341. [CrossRef]

8. Prasad, A.S. Clinical, endocrinological and biochemical effects of zinc deficiency. Clin. Endocrinol. Metab. 1985, 14, 567-589. [CrossRef]

9. Cousins, R.J. Zinc. Present Knowledge in Nutrition, 9th ed.; Brown Bowman, B.A., Russell, R.M., Eds.; International Life Science Institute (ILSI) Press: Washington, DC, USA, 2006; Volume 1, pp. 225-457.

10. Ha, N.; Hellauer, K.; Turcotte, B. Mutations in target DNA elements of yeast HAP1 modulate its transcriptional activity without affecting DNA binding. Nucl. Acids Res. 1996, 24, 1453-1459. [CrossRef]

11. Beyersmann, D.; Haase, H. Functions of zinc in signaling, proliferation and differentiation of mammalian cells. Biometals 2001, 14, 331-341. [CrossRef]

12. Tate, D.J., Jr.; Miceli, M.V.; Newsome, D.A. Zinc protects against oxidative damage in cultured human retinal pigment epithelial cells. Free Radic. Biol. Med. 1999, 26, 704-713. [CrossRef] 
13. Henderson, L.M.; Chappell, J.B.; Jones, O.T. Superoxide generation by the electrogenic NADPH oxidase of human neutrophils is limited by the movement of a compensating charge. Biochem. J. 1988, 255, 285-290. [PubMed]

14. Musset, B.; Decoursey, T. Biophysical properties of the voltage gated proton channel H(V)1. Wiley Interdiscip. Rev. Membr. Transp. Signal. 2012, 1, 605-620. [CrossRef] [PubMed]

15. Cousins, R.J.; Liuzzi, J.P.; Lichten, L.A. Mammalian zinc transport, trafficking, and signals. J. Biol. Chem. 2006, 281, 24085-24089. [CrossRef]

16. Cassandri, M.; Smirnov, A.; Novelli, F.; Pitolli, C.; Agostini, M.; Malewicz, M.; Melino, G.; Raschella, G. Zinc-finger proteins in health and disease. Cell Death Discov. 2017, 3, 17071. [CrossRef]

17. Prasad, A.S. Effects of zinc deficiency on Th1 and Th2 cytokine shifts. J. Infect. Dis. 2000, 182 (Suppl. S1), S62-S68. [CrossRef]

18. Ibs, K.H.; Rink, L. Zinc-altered immune function. J. Nutr. 2003, 133, 1452S-1456S. [CrossRef]

19. Bogden, J.D. Influence of zinc on immunity in the elderly. J. Nutr. Health Aging 2004, 8, 48-54.

20. Mocchegiani, E.; Giacconi, R.; Cipriano, C.; Malavolta, M. NK and NKT cells in aging and longevity: Role of zinc and metallothioneins. J. Clin. Immunol. 2009, 29, 416-425. [CrossRef]

21. Barzegar-Befroei, N.; Cahyadi, S.; Gango, A.; Peto, T.; Lengyel, I. Zinc and eye diseases. In Zinc in Human Health; Rink, L., Ed.; IOS Press: Amsterdam, the Netherlands, 2011. [CrossRef]

22. Ugarte, M.; Osborne, N.N. Zinc in the retina. Progr. Neurobiol. 2001, 64, 219-249. [CrossRef]

23. Boulton, M.; Dayhaw-Barker, P. The role of the retinal pigment epithelium: Topographical variation and ageing changes. Eye (London) 2001, 15, 384-389. [CrossRef] [PubMed]

24. Tan, A.C.S.; Pilgrim, M.G.; Fearn, S.; Bertazzo, S.; Tsolaki, E.; Morrell, A.P.; Li, M.; Messinger, J.D.; Dolz-Marco, R.; Lei, J.; et al. Calcified nodules in retinal drusen are associated with disease progression in age-related macular degeneration. Sci. Transl. Med. 2018, 10. [CrossRef] [PubMed]

25. Gass, J.D. Drusen and disciform macular detachment and degeneration. 1972. Retina 2003, 23, 409-436. [PubMed]

26. Ferris, F.L.; Davis, M.D.; Clemons, T.E.; Lee, L.Y.; Chew, E.Y.; Lindblad, A.S.; Milton, R.C.; Bressler, S.B.; Klein, R. A simplified severity scale for age-related macular degeneration: AREDS report No. 18. Arch. Ophthalmol. 2005, 123, 1570-1574. [PubMed]

27. Ferris, F.L., III; Wilkinson, C.P.; Bird, A.; Chakravarthy, U.; Chew, E.; Csaky, K.; Sadda, S.R. Clinical classification of age-related macular degeneration. Ophthalmology 2013, 120, 844-851. [CrossRef]

28. Gong, J.; Cai, H.; Noggle, S.; Paull, D.; Rizzolo, L.J.; Del Priore, L.V.; Fields, M.A. Stem cell-derived retinal pigment epithelium from patients with age-related macular degeneration exhibit reduced metabolism and matrix interactions. Stem Cells Transl Med. 2020, 9, 364-376. [CrossRef]

29. Fernandez-Godino, R. Alterations in Extracellular Matrix/Bruch's Membrane Can Cause the Activation of the Alternative Complement Pathway via Tick-Over. Adv. Exp. Med. Biol. 2018, 1074, 29-35. [CrossRef]

30. Fernandez-Godino, R.; Pierce, E.A. C3a triggers formation of sub-retinal pigment epithelium deposits via the ubiquitin proteasome pathway. Sci. Rep. 2018, 8, 9679. [CrossRef]

31. Fernandez-Godino, R.; Pierce, E.A.; Garland, D.L. Extracellular matrix alterations and deposit formation in AMD. Adv. Exp. Med. Biol. 2016, 854, 53-58. [CrossRef]

32. Lakkaraju, A.; Umapathy, A.; Tan, L.X.; Daniele, L.; Philp, N.J.; Boesze-Battaglia, K.; Williams, D.S. The cell biology of the retinal pigment epithelium. Progr Retin. Eye Res. 2020, 100846. [CrossRef]

33. Chen, X.; Singh, D.; Adelman, R.A.; Rizzolo, L.J. Unstimulated, serum-free cultures of retinal pigment epithelium excrete large mounds of drusen-like deposits. Curr. Eye Res. 2020, 1-5. [CrossRef] [PubMed]

34. Pilgrim, M.G.; Lengyel, I.; Lanzirotti, A.; Newville, M.; Fearn, S.; Emri, E.; Knowles, J.C.; Messinger, J.D.; Read, R.W.; Guidry, C.; et al. Subretinal pigment epithelial deposition of drusen components including hydroxyapatite in a primary cell culture model. Investig. Ophthalmol. Vis. Sci. 2017, 58, 708-719. [CrossRef] [PubMed]

35. Galloway, C.A.; Dalvi, S.; Hung, S.S.C.; MacDonald, L.A.; Latchney, L.R.; Wong, R.C.B.; Guymer, R.H.; Mackey, D.A.; Williams, D.S.; Chung, M.M.; et al. Drusen in patient-derived hiPSC-RPE models of macular dystrophies. Proc. Natl. Acad. Sci. USA 2017, 114, E8214-E8223. [CrossRef] [PubMed]

36. Erie, J.C.; Good, J.A.; Butz, J.A.; Pulido, J.S. Reduced zinc and copper in the retinal pigment epithelium and choroid in age-related macular degeneration. Am. J. Ophthalmol. 2009, 147, 276-282. [CrossRef] [PubMed] 
37. Newsome, D.A.; Micelli, M.V.; Tate, D., Jr.; Alcock, N.W.; Oliver, P.D. Zinc content of human retinal pigment epithelium decreases with age and macular degeneration, but superoxide dismutase activity increases. J. Trace Elem. Exp. Med. 1996, 8, 193-199. [CrossRef]

38. Pao, P.J.; Emri, E.; Abdirahman, S.B.; Soorma, T.; Zeng, H.H.; Hauck, S.M.; Thompson, R.B.; Lengyel, I. The effects of zinc supplementation on primary human retinal pigment epithelium. J. Trace Elem. Med. Biol. 2018, 49, 184-191. [CrossRef] [PubMed]

39. Bozym, R.A.; Chimienti, F.; Giblin, L.J.; Gross, G.W.; Korichneva, I.; Li, Y.; Libert, S.; Maret, W.; Parviz, M.; Frederickson, C.J.; et al. Free zinc ions outside a narrow concentration range are toxic to a variety of cells in vitro. Exp. Biol. Med. (Maywood) 2010, 235, 741-750. [CrossRef]

40. Yokoyama, M.; Koh, J.; Choi, D.W. Brief exposure to zinc is toxic to cortical neurons. Neurosci. Lett. 1986, 71, 351-355. [CrossRef]

41. Weiss, J.H.; Hartley, D.M.; Koh, J.Y.; Choi, D.W. AMPA receptor activation potentiates zinc neurotoxicity. Neuron 1993, 10, 43-49. [CrossRef]

42. Tate, D.J.; Miceli, M.V.; Newsome, D.A.; Alcock, N.W.; Oliver, P.D. Influence of zinc on selected cellular functions of cultured human retinal pigment epithelium. Curr. Eye Res. 1995, 14, 897-903. [CrossRef]

43. Song, J.; Lee, S.C.; Kim, S.S.; Koh, H.J.; Kwon, O.W.; Kang, J.J.; Kim, E.K.; Shin, S.H.; Lee, J.H. Zn2+-induced cell death is mediated by the induction of intracellular ROS in ARPE-19 cells. Curr. Eye Res. 2004, 28, 195-201. [CrossRef] [PubMed]

44. Bozym, R.; Hurst, T.K.; Westerberg, N.; Stoddard, A.; Fierke, C.A.; Frederickson, C.J.; Thompson, R.B. Determination of zinc using carbonic anhydrase-based fluorescence biosensors. Methods Enzymol. 2008, 450, 287-309. [CrossRef] [PubMed]

45. Maminishkis, A.; Chen, S.; Jalickee, S.; Banzon, T.; Shi, G.; Wang, F.E.; Ehalt, T.; Hammer, J.A.; Miller, S.S. Confluent monolayers of cultured human fetal retinal pigment epithelium exhibit morphology and physiology of native tissue. Investig. Ophthalmol. Vis. Sci. 2006, 47, 3612-3624. [CrossRef] [PubMed]

46. Sonoda, S.; Spee, C.; Barron, E.; Ryan, S.J.; Kannan, R.; Hinton, D.R. A protocol for the culture and differentiation of highly polarized human retinal pigment epithelial cells. Nat. Protoc. 2009, 4, 662-673. [CrossRef] [PubMed]

47. De Breuk, A.; Acar, I.E.; Kersten, E.; Schijvenaars, M.V.A.P.; Colijn, J.M.; Haer-Wigman, L.; Bakker, B.; De Jong, S.; Meester-Smoor, M.A.; Verzijden, T.; et al. Development of a genotype assay for age-related macular degeneration: the EYE-RISK Consortium. Ophthalmology 2020, in press.

48. Buitendijk, G.H.S.; Rochtchina, E.; Myers, C.; Van Duijn, C.M.; Lee, K.E.; Klein, B.E.K.; Meuer, S.M.; De Jong, P.; Holliday, E.G.; Tan, A.G.; et al. Prediction of age-related macular degeneration in the general population: the Three Continent AMD Consortium. Ophthalmology 2013, 120, 2644-2655. [CrossRef]

49. Robinson, M.D.; McCarthy, D.J.; Smyth, G.K. edgeR: a bioconductor package for differential expression analysis of digital gene expression data. Bioinformatics 2010, 26, 139-140. [CrossRef]

50. Coman, C.; Solari, F.A.; Hentschel, A.; Sickmann, A.; Zahedi, R.P.; Ahrends, R. Simultaneous metabolite, protein, lipid extraction (SIMPLEX): a combinatorial multimolecular omics approach for systems biology. Mol. Cell. Proteom. 2016, 15, 1453-1466. [CrossRef]

51. Cox, J.; Mann, M. MaxQuant enables high peptide identification rates, individualized p.p.b.-range mass accuracies and proteome-wide protein quantification. Nat. Biotechnol. 2008, 26, 1367-1372. [CrossRef]

52. Vizcaíno, J.A.; Csordas, A.; Del-Toro, N.; Dianes, J.A.; Griss, J.; Lavidas, I.; Mayer, G.; Perez-Riverol, Y.; Reisinger, F.; Ternent, T.; et al. 2016 update of the PRIDE database and its related tools. Nucl. Acids Res. 2016, 44, D447-D456. [CrossRef]

53. Huang da, W.; Sherman, B.T.; Lempicki, R.A. Systematic and integrative analysis of large gene lists using DAVID bioinformatics resources. Nat. Protoc. 2009, 4, 44-57. [CrossRef] [PubMed]

54. Huang da, W.; Sherman, B.T.; Lempicki, R.A. Bioinformatics enrichment tools: Paths toward the comprehensive functional analysis of large gene lists. Nucl. Acids Res. 2009, 37, 1-13. [CrossRef] [PubMed]

55. Lorés-Motta, L.; Paun, C.C.; Corominas, J.; Pauper, M.; Geerlings, M.J.; Altay, L.; Schick, T.; Daha, M.R.; Fauser, S.; Hoyng, C.B.; et al. Genome-wide association study reveals variants in CFH and CFHR4 associated with systemic complement activation: Implications in age-related macular degeneration. Ophthalmology 2018, 125, 1064-1074. [CrossRef] [PubMed] 
56. Han, X.; Gharahkhani, P.; Mitchell, P.; Liew, G.; Hewitt, A.W.; MacGregor, S. Genome-wide meta-analysis identifies novel loci associated with age-related macular degeneration. J. Hum. Genet. 2020, 65, 657-665. [CrossRef]

57. Johnson, L.V.; Forest, D.L.; Banna, C.D.; Radeke, C.M.; Maloney, M.A.; Hu, J.; Spencer, C.N.; Walker, A.M.; Tsie, M.S.; Bok, D.; et al. Cell culture model that mimics drusen formation and triggers complement activation associated with age-related macular degeneration. Proc. Natl. Acad. Sci. USA 2011, 108, 18277-18282. [CrossRef]

58. Amin, S.; Chong, N.H.; Bailey, T.A.; Zhang, J.; Knupp, C.; Cheetham, M.E.; Greenwood, J.; Luthert, P.J. Modulation of Sub-RPE deposits in vitro: a potential model for age-related macular degeneration. Invest Ophthalmol. Vis. Sci. 2004, 45, 1281-1288. [CrossRef]

59. Krämer, A.; Green, J.; Pollard, J., Jr.; Tugendreich, S. Causal analysis approaches in ingenuity pathway analysis. Bioinformatics 2014, 30, 523-530. [CrossRef]

60. Age-Related Eye Disease Study Research Group. The age-related eye disease study (AREDS): Design implications. AREDS report no. 1. Control Clin. Trials 1999, 20, 573-600. [CrossRef]

61. Hofman, A.; Grobbee, D.E.; De Jong, P.T.; Van den Ouweland, F.A. Determinants of disease and disability in the elderly: the Rotterdam Elderly Study. Eur. J. Epidemiol. 1991, 7, 403-422. [CrossRef]

62. Mitchell, P.; Smith, W.; Wang, J.J. Iris color, skin sun sensitivity, and age-related maculopathy. The Blue Mountains Eye Study. Ophthalmology 1998, 105, 1359-1363. [CrossRef]

63. Chew, E.Y.; Clemons, T.E.; Agron, E.; Sperduto, R.D.; Sangiovanni, J.P.; Kurinij, N.; Davis, M.D. Long-term effects of vitamins $\mathrm{C}$ and $\mathrm{E}$, beta-carotene, and zinc on age-related macular degeneration: AREDS report no. 35. Ophthalmology 2013, 120, 1604-1611. [CrossRef] [PubMed]

64. King, J.C.; Shames, D.M.; Woodhouse, L.R. Zinc homeostasis in humans. J. Nutr. 2000, 130, 1360S-1366S. [CrossRef] [PubMed]

65. Gonzalez-Iglesias, H.; Alvarez, L.; García, M.; Petrash, C.; Sanz-Medel, A.; Coca-Prados, M. Metallothioneins (MTs) in the human eye: a perspective article on the zinc-MT redox cycle. Metallomics 2014, 6, 201-208. [CrossRef] [PubMed]

66. Rodríguez-Menéndez, S.; García, M.; Fernández, B.; Álvarez, L.; Fernández-Vega-Cueto, A.; Coca-Prados, M.; Pereiro, R.; González-Iglesias, H. The zinc-metallothionein redox system reduces oxidative stress in retinal pigment epithelial cells. Nutrients 2018, 10, 1874. [CrossRef]

67. Tate, D.J.; Newsome, D.A. A novel zinc compound (zinc monocysteine) enhances the antioxidant capacity of human retinal pigment epithelial cells. Curr. Eye Res. 2006, 31, 675-683. [CrossRef]

68. Parat, M.O.; Richard, M.J.; Béani, J.C.; Favier, A. Involvement of zinc in intracellular oxidant/antioxidant balance. Biol. Trace Elem. Res. 1997, 60, 187-204. [CrossRef]

69. Nakatani, T.; Tawaramoto, M.; Opare Kennedy, D.; Kojima, A.; Matsui-Yuasa, I. Apoptosis induced by chelation of intracellular zinc is associated with depletion of cellular reduced glutathione level in rat hepatocytes. Chem. Biol. Interact. 2000, 125, 151-163. [CrossRef]

70. Bray, T.M.; Bettger, W.J. The physiological role of zinc as an antioxidant. Free Radic. Biol. Med. 1990, 8, 281-291. [CrossRef]

71. Jarosz, M.; Olbert, M.; Wyszogrodzka, G.; Młyniec, K.; Librowski, T. Antioxidant and anti-inflammatory effects of zinc. Zinc-dependent NF-kB signaling. Inflammopharmacology 2017, 25, 11-24. [CrossRef]

72. Oteiza, P.I. Zinc and the modulation of redox homeostasis. Free Radic. Biol. Med. 2012, 53, 1748-1759. [CrossRef]

73. Vishwanathan, R.; Chung, M.; Johnson, E.J. A systematic review on zinc for the prevention and treatment of age-related macular degeneration. Investig. Ophthalmol. Vis. Sci. 2013, 54, 3985-3998. [CrossRef] [PubMed]

74. Agron, E.; Mares, J.A.; Clemons, T.E.; Swaroop, A.; Chew, E.Y.; Keenan, T.D.L. AREDS and AREDS2 Research Groups. Dietary nutrient intake and progression to late age-related macular degeneration in the Age-Related Eye Disease studies 1 and 2. Ophthalmology 2020. [CrossRef] [PubMed]

75. Thompson, R.B.; Reffatto, V.; Bundy, J.G.; Kortvely, E.; Flinn, J.M.; Lanzirotti, A.; Jones, E.A.; McPhail, D.S.; Fearn, S.; Boldt, K.; et al. Identification of hydroxyapatite spherules provides new insight into subretinal pigment epithelial deposit formation in the aging eye. Proc. Natl. Acad. Sci. USA 2015, 112, 1565-1570. [CrossRef] [PubMed] 
76. Zorlu, Y.; Brown, C.; Keil, C.; Ayhan, M.M.; Haase, H.; Thompson, R.B.; Lengyel, I.; Yücesan, G. Fluorescent arylphosphonic acids: Synergic interactions between bone and the fluorescent core. Chemistry 2020. [CrossRef] [PubMed]

77. Szmacinski, H.; Hegde, K.; Zeng, H.H.; Eslami, K.; Puche, A.C.; Lengyel, I.; Thompson, R.B. Imaging hydroxyapatite in sub-retinal pigment epithelial deposits by fluorescence lifetime imaging microscopy with tetracycline staining. J. Biomed. Opt. 2020, 25, 1-11. [CrossRef] [PubMed]

78. Bennis, A.; Jacobs, J.G.; Catsburg, L.A.E.; Ten Brink, J.B.; Koster, C.; Schlingemann, R.O.; Van Meurs, J.; Gorgels, T.; Moerland, P.D.; Heine, V.M.; et al. Stem cell derived retinal pigment epithelium: the role of pigmentation as maturation marker and gene expression profile comparison with human endogenous retinal pigment epithelium. Stem Cell Rev. Rep. 2017, 13, 659-669. [CrossRef] [PubMed]

79. Balaratnasingam, C.; Yannuzzi, L.A.; Curcio, C.A.; Morgan, W.H.; Querques, G.; Capuano, V.; Souied, E.; Jung, J.; Freund, K.B. Associations between retinal pigment epithelium and drusen volume changes during the lifecycle of large drusenoid pigment epithelial detachments. Investig. Ophthalmol. Vis. Sci. 2016, 57, 5479-5489. [CrossRef] [PubMed]

80. Curcio, C.A.; Zanzottera, E.C.; Ach, T.; Balaratnasingam, C.; Freund, K.B. Activated retinal pigment epithelium, an optical coherence tomography biomarker for progression in age-related macular degeneration. Investig. Ophthalmol. Vis. Sci. 2017, 58, BIO211-BIO226.

81. Stojanovic, A.; Stitham, J.; Hwa, J. Critical role of transmembrane segment zinc binding in the structure and function of rhodopsin. J. Biol. Chem. 2004, 279, 35932-35941. [CrossRef] [PubMed]

82. Gleim, S.; Stojanovic, A.; Arehart, E.; Byington, D.; Hwa, J. Conserved rhodopsin intradiscal structural motifs mediate stabilization: Effects of zinc. Biochemistry 2009, 48, 1793-1800. [CrossRef] [PubMed]

83. Toledo, D.; Cordomi, A.; Proietti, M.G.; Benfatto, M.; Del Valle, L.J.; Perez, J.J.; Garriga, P.; Sepulcre, F. Structural characterization of a zinc high-affinity binding site in rhodopsin. Photochem. Photobiol. 2009, 85, 479-484. [CrossRef] [PubMed]

84. Galin, M.A.; Nano, H.D.; Hall, T. Ocular zinc concentration. Investig. Ophthalmol. 1962, 1, 142-148.

85. Leung, K.W.; Liu, M.; Xu, X.; Seiler, M.J.; Barnstable, C.J.; Tombran-Tink, J. Expression of ZnT and ZIP zinc transporters in the human RPE and their regulation by neurotrophic factors. Investig. Ophthalmol. Vis. Sci. 2008, 49, 1221-1231. [CrossRef]

86. Leung, K.W.; Gvritishvili, A.; Liu, Y.; Tombran-Tink, J. ZIP2 and ZIP4 mediate age-related zinc fluxes across the retinal pigment epithelium. J. Mol. Neurosci. 2012, 46, 122-137. [CrossRef]

87. Redenti, S.; Chappell, R.L. Müller cell zinc transporter-3 labeling suggests a role in outer retina zinc homeostasis. Mol. Med. 2007, 13, 376-379. [CrossRef]

88. Ugarte, M.; Osborne, N.N. The localization of free zinc varies in rat photoreceptors during light and dark adaptation. Exp. Eye Res. 1999, 69, 459-461. [CrossRef] [PubMed]

89. Hirayama, Y. Histochemical localization of zinc and copper in rat ocular tissues. Acta Histochem. 1990, 89, 107-111. [CrossRef]

90. Pålsgård, E.; Ugarte, M.; Rajta, I.; Grime, G.W. The role of zinc in the dark-adapted retina studied directly using microPIXE. In Beam Interactions with Materials and Atoms, Proceedings of the 7 th International Conference on Nuclear Microprobe Technology and Applications, Bordeaux, France, 10-15 September 2000; Elsevier: Amsterdam, the Netherlands, 2001; Volume 181, pp. 489-492. [CrossRef]

91. Olsson, J.E.; Gordon, J.W.; Pawlyk, B.S.; Roof, D.; Hayes, A.; Molday, R.S.; Mukai, S.; Cowley, G.S.; Berson, E.L.; Dryja, T.P. Transgenic mice with a rhodopsin mutation (Pro23His): a mouse model of autosomal dominant retinitis pigmentosa. Neuron 1992, 9, 815-830. [CrossRef]

92. Zhao, C.; Yasumura, D.; Li, X.; Matthes, M.; Lloyd, M.; Nielsen, G.; Ahern, K.; Snyder, M.; Bok, D.; Dunaief, J.L.; et al. mTOR-mediated dedifferentiation of the retinal pigment epithelium initiates photoreceptor degeneration in mice. J. Clin. Investig. 2011, 121, 369-383. [CrossRef]

93. Gammoh, N.Z.; Rink, L. Zinc in Infection and inflammation. Nutrients 2017, 9, 624. [CrossRef]

94. Anderson, D.H.; Mullins, R.F.; Hageman, G.S.; Johnson, L.V. A role for local inflammation in the formation of drusen in the aging eye. Am. J. Ophthalmol. 2002, 134, 411-431. [CrossRef]

95. Gehrs, K.M.; Jackson, J.R.; Brown, E.N.; Allikmets, R.; Hageman, G.S. Complement, age-related macular degeneration and a vision of the future. Arch. Ophthalmol. 2010, 128, 349-358. [CrossRef] [PubMed] 
96. Hageman, G.S.; Luthert, P.J.; Victor Chong, N.H.; Johnson, L.V.; Anderson, D.H.; Mullins, R.F. An integrated hypothesis that considers drusen as biomarkers of immune-mediated processes at the RPE-Bruch's membrane interface in aging and age-related macular degeneration. Progr. Retin. Eye Res. 2001, 20, 705-732. [CrossRef]

97. Van Leeuwen, E.M.; Emri, E.; Merle, B.M.J.; Colijn, J.M.; Kersten, E.; Cougnard-Gregoire, A.; Dammeier, S.; Meester-Smoor, M.; Pool, F.M.; De Jong, E.K.; et al. A new perspective on lipid research in age-related macular degeneration. Progr. Retin. Eye Res. 2018, 67, 56-86. [CrossRef]

98. Smailhodzic, D.; Van Asten, F.; Blom, A.M.; Mohlin, F.C.; Den Hollander, A.I.; Van de Ven, J.P.; Van Huet, R.A.; Groenewoud, J.M.; Tian, Y.; Berendschot, T.T.; et al. Zinc supplementation inhibits complement activation in age-related macular degeneration. PLoS ONE 2014, 9, e112682. [CrossRef]

99. Awh, C.C.; Hawken, S.; Zanke, B.W. Treatment response to antioxidants and zinc based on CFH and ARMS2 genetic risk allele number in the Age-Related Eye Disease Study. Ophthalmology 2015, 122, 162-169. [CrossRef] [PubMed]

100. Chew, E.Y.; Klein, M.L.; Clemons, T.E.; Agrón, E.; Ratnapriya, R.; Edwards, A.O.; Fritsche, L.G.; Swaroop, A.; Abecasis, G.R. No clinically significant association between CFH and ARMS2 genotypes and response to nutritional supplements: AREDS report number 38. Ophthalmology 2014, 121, 2173-2180. [CrossRef]

101. Ma, W.; Silverman, S.M.; Zhao, L.; Villasmil, R.; Campos, M.M.; Amaral, J.; Wong, W.T. Absence of TGF $\beta$ signaling in retinal microglia induces retinal degeneration and exacerbates choroidal neovascularization. Elife 2019, 8, e42049. [CrossRef]

102. Yang, X.; Zhao, L.; Campos, M.M.; Abu-Asab, M.; Ortolan, D.; Hotaling, N.; Bharti, K.; Wong, W.T. CSF1R blockade induces macrophage ablation and results in mouse choroidal vascular atrophy and RPE disorganization. Elife 2020, 9, e55564. [CrossRef]

103. Tosi, G.M.; Orlandini, M.; Galvagni, F. The Controversial Role of TGF- $\beta$ in Neovascular age-related macular degeneration pathogenesis. Int. J. Mol. Sci. 2018, 19, 3363. [CrossRef]

104. Tanihara, H.; Yoshida, M.; Matsumoto, M.; Yoshimura, N. Identification of transforming growth factor-beta expressed in cultured human retinal pigment epithelial cells. Investig. Ophthalmol. Vis. Sci. 1993, 34, 413-419.

105. Pérez-Sala, D.; Oeste, C.L.; Martínez, A.E.; Carrasco, M.J.; Garzón, B.; Cañada, F.J. Vimentin filament organization and stress sensing depend on its single cysteine residue and zinc binding. Nat. Commun. 2015, 6, 7287. [CrossRef]

106. Ghosh, S.; Shang, P.; Terasaki, H.; Stepicheva, N.; Hose, S.; Yazdankhah, M.; Weiss, J.; Sakamoto, T.; Bhutto, I.A.; Xia, S.; et al. A role for $\beta$ A3/A1-crystallin in type 2 EMT of RPE cells occurring in dry age-related macular degeneration. Investig. Ophthalmol. Vis. Sci. 2018, 59, AMD104-AMD113. [CrossRef] [PubMed]

107. Guidry, C.; Medeiros, N.E.; Curcio, C.A. Phenotypic variation of retinal pigment epithelium in age-related macular degeneration. Investig. Ophthalmol. Vis. Sci. 2002, 43, 267-273.

108. Sethi, C.S.; Bailey, T.A.; Luthert, P.J.; Chong, N.H. Matrix metalloproteinase biology applied to vitreoretinal disorders. Br. J. Ophthalmol. 2000, 84, 654-666. [CrossRef]

109. Guo, L.; Hussain, A.A.; Limb, G.A.; Marshall, J. Age-dependent variation in metalloproteinase activity of isolated human Bruch's membrane and choroid. Investig. Ophthalmol. Vis. Sci. 1999, 40, 2676-2682.

110. Steen, B.; Sejersen, S.; Berglin, L.; Seregard, S.; Kvanta, A. Matrix metalloproteinases and metalloproteinase inhibitors in choroidal neovascular membranes. Investig. Ophthalmol. Vis. Sci. 1998, 39, 2194-2200.

111. Nita, M.; Strzałka-Mrozik, B.; Grzybowski, A.; Mazurek, U.; Romaniuk, W. Age-related macular degeneration and changes in the extracellular matrix. Med. Sci. Monit. 2014, 20, 1003-1016.

112. Lazzarini, R.; Nicolai, M.; Pirani, V.; Mariotti, C.; Di Primio, R. Effects of senescent secretory phenotype acquisition on human retinal pigment epithelial stem cells. Aging (Albany N.Y.) 2018, 10, 3173-3184. [CrossRef]

113. Jiang, C.; Xie, P.; Sun, R.; Sun, X.; Liu, G.; Ding, S.; Zhu, M.; Yan, B.; Liu, Q.; Chen, X.; et al. c-Jun-mediated microRNA-302d-3p induces RPE dedifferentiation by targeting p21(Waf1/Cip1). Cell Death Dis. 2018, 9, 451. [CrossRef]

114. Strnad, P.; McElvaney, N.G.; Lomas, D.A. Alpha(1)-Antitrypsin Deficiency. N. Engl. J. Med. 2020, 382, 1443-1455. [CrossRef] [PubMed]

115. Crabb, J.W.; Miyagi, M.; Gu, X.; Shadrach, K.; West, K.A.; Sakaguchi, H.; Kamei, M.; Hasan, A.; Yan, L.; Rayborn, M.E.; et al. Drusen proteome analysis: an approach to the etiology of age-related macular degeneration. Proc. Natl. Acad. Sci. USA 2002, 99, 14682-14687. [CrossRef] [PubMed] 
116. Koss, M.J.; Hoffmann, J.; Nguyen, N.; Pfister, M.; Mischak, H.; Mullen, W.; Husi, H.; Rejdak, R.; Koch, F.; Jankowski, J.; et al. Proteomics of vitreous humor of patients with exudative age-related macular degeneration. PLoS ONE 2014, 9, e96895. [CrossRef] [PubMed]

117. Szemraj, M.; Oszajca, K.; Szemraj, J.; Jurowski, P. MicroRNA Expression analysis in serum of patients with congenital hemochromatosis and age-related macular degeneration (AMD). Med. Sci. Monit. 2017, 23, 4050-4060. [CrossRef] [PubMed]

118. Blasiak, J.; Watala, C.; Tuuminen, R.; Kivinen, N.; Koskela, A.; Uusitalo-Jarvinen, H.; Tuulonen, A.; Winiarczyk, M.; Mackiewicz, J.; Zmorzynski, S.; et al. Expression of VEGFA-regulating miRNAs and mortality in wet AMD. J. Cell. Mol. Med. 2019, 23, 8464-8471. [CrossRef] [PubMed]

119. Gotte, M.; Mohr, C.; Koo, C.Y.; Stock, C.; Vaske, A.K.; Viola, M.; Ibrahim, S.A.; Peddibhotla, S.; Teng, Y.H.; Low, J.Y.; et al. miR-145-dependent targeting of junctional adhesion molecule a and modulation of fascin expression are associated with reduced breast cancer cell motility and invasiveness. Oncogene 2010, 29, 6569-6580. [CrossRef]

120. Cho, Y.; Cao, X.; Shen, D.; Tuo, J.; Parver, L.M.; Rickles, F.R.; Chan, C.C. Evidence for enhanced tissue factor expression in age-related macular degeneration. Lab. Investig. 2011, 91, 519-526. [CrossRef]

121. Hu, Z.; Cheng, J.; Xu, J.; Ruf, W.; Lockwood, C.J. Tissue factor is an angiogenic-specific receptor for factor VII-targeted immunotherapy and photodynamic therapy. Angiogenesis 2017, 20, 85-96. [CrossRef]

122. Dunaief, J.L.; Dentchev, T.; Ying, G.S.; Milam, A.H. The role of apoptosis in age-related macular degeneration. Arch. Ophthalmol. 2002, 120, 1435-1442. [CrossRef]

123. Tasharrofi, N.; Kouhkan, F.; Soleimani, M.; Soheili, Z.S.; Kabiri, M.; Mahmoudi Saber, M.; Dorkoosh, F.A. Survival improvement in human retinal pigment epithelial cells via fas receptor targeting by miR-374a. J. Cell. Biochem. 2017, 118, 4854-4861. [CrossRef]

(C) 2020 by the authors. Licensee MDPI, Basel, Switzerland. This article is an open access article distributed under the terms and conditions of the Creative Commons Attribution (CC BY) license (http://creativecommons.org/licenses/by/4.0/). 